MA-thesis in International Affairs

Conflict in the Democratic Republic of the Congo A study of "new wars"

Erna Sif Bjarnadóttir

October 2017

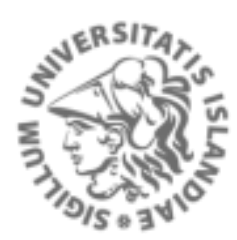

HÁSKÓLI ÍSLANDS 


\section{Conflict in the Democratic Republic of the Congo}

A study of "new wars"

Erna Sif Bjarnadóttir

MA thesis in International Affairs

Advisor: Silja Bára Ómarsdóttir

Faculty of Political Science

School of Social Science

University of Iceland

September 2017 
Conflict in the Democratic Republic of the Congo: A study of "new wars"

This thesis is submitted in partial fulfilment of the requirements for the Degree of Master of Arts in International Affairs at the University of Iceland. The thesis cannot be reproduced without the author's consent.

(C) Erna Sif Bjarnadóttir 2017

291089-2599

Reykjavík, Iceland 2017 



\begin{abstract}
The Congo Wars from 1996-2003 are known as the deadliest wars since World War II. Several attempts have been made to analyse the causes of the two Congo Wars with different theoretical aspects, however, few attempts have been made to explain and analyse the nature of the wars in the Congo from 1996-2003. The aim of this research was to test Mary Kaldor's theory of "new and old wars" on the case of the Congo Wars 1996-2003. The central argument of Kaldor's theory is that during the last decade of the twentieth century, organised violence and warfare changed dramatically vis-à-vis actors, aims, economy, and victims. In this thesis, I conduct a single case study analysis, and I find that in accordance with Kaldor's theory, we do see in the case of the Congo Wars a new set of actors, new aims, new war economy, and new systematically targeted victims. I analyse the nature of the wars and place special emphasis on explaining the actors, aims, economy, and victims. My hope is that this research deepens discussions of warfare in the twenty-first century and helps policy makers develop their responses to this new type of warfare.
\end{abstract}




\section{Úrdráttur}

Kongó stríðin tvö frá 1996 til 2003 eru áltin vera ein af banvænustu stríðum seinni hluta 20. aldar. Margar tilraunir hafa verið gerðar til pess að rannsaka margvíslegu ástæðurnar á bakvið pau með mismunandi aðferðafræðilegum nálgunum en fáar tilraunir hafa verið gerðar til pess að útskýra eðli stríðanna. Markmið pessarar rannsóknar er að prófa kenningu Mary Kaldor um „ný og gömul stríð“ (e. “new and old wars”). Megin röksemdarfærsla Kaldor er sú að á síðustu áratugum 20. aldar breyttist hernaður í tengslum við gerendur, efnahag, markmið og fórnalömb. Pessi ritgerð er tilviksrannsókn á stríðin tvö í Kongó 1996-2003 með pað markmið að prófa kenningu Kaldor. Rannsóknin beinist að eðli stríðanna með sérstaka áherslu á að skýra gerendur, markmið, efnahag og fórnalömb peirra. Niðurstöðurnar leggja til að í tilfelli í Kongó sjáum við breytingu í hernað; nýja tegund af gerendum, ný markmið, nýjan „stríðs efnahag“ og markvissa breytingu í fórnalömbum stríðunum. Mín von er sú að pessi rannsókn dýpki umræður um hernað á 21. öldinni og hjálpi stefnumótunaraðilum að próa frekari viðbrögð við pessari nýju tegund af hernaði. 


\section{Preface}

This thesis is submitted in partial fulfilment of the degree of Master of Arts in International Affairs at the University of Iceland. It comprises 30 ECTS. This thesis was conducted under the supervision of Silja Bára Ómarsdóttir, who receives my gratitude for advice, constructive comments, immense patience, and overall support. I would also like to thank my sisters, Júlía, Heiða and Kristrún for tremendous emotional support during these last few months. Lastly I would like to thank my father, Bjarni Ásmundsson, for always being there.

Erna Sif Bjarnadóttir

Reykjavík, $7^{\text {th }}$ September 2017 
Abstract

Úrdráttur___ ii

Preface __ iii

1. Introduction ___ 3

2. Theoretical Framework___ 6

2.1 "Old wars" ___ 6

2.2 "New wars" ___ _ _ _ 8

2.2.1 Globalisation 8

2.2.2 New actors, aims, victims and economy ___ 9

2.2.3 Summary __ 12

2.3 Critique ___ 12

2.3.1 Are "new wars", "war"? 12

2.3.2 The question of the evidence 14

2.3.3 Are "new wars" new? _ـ 15

2.3.4 Summary __ 16

2.4 Alternative theoretical approaches ___ 16

2.5 The case in context ___ 20

3. Methodology ___ 22

3.1 Qualitative research ___ 22

3.1.1 Within-case analysis__ 24

3.2 Significance/Relevance________________ 25

3.3 Ethical issues ___ 25

3.4 Execution______ 26

3.5. Limits to the research ___ 26

4. The Congo Wars__ 28

4.1 Actors 28

4.1.1 First Congo War 29

4.1.2. Second Congo War _ 31

4.2 "War of Liberation" and "The Great African War" ____ 34

4.3 Analysis ___ 41

4.4 Aims and resources ___ 43

4.4.1 Globalisation _ 43

4.4.2 First Congo War 43

4.4.3 Second Congo War 44

4.5 Analysis ___ 45

4.6 Victims ___ 46

4.6.1 First Congo War 47

4.6.2 Second Congo War 49

4.7 Analysis ___ 50

5. Conclusions __ 52 
6. Discussions 56

Bibliography 59

Appendix A - Timeline 69

Appendix B - Key fighting units in the Congo Wars 82

Appendix C - Key individual actors in the Congo Wars 86

Appendix D - Maps 89 


\section{Introduction}

Since the end of the Cold War, the nature of war and warfare has changed dramatically. Common consensus holds that the world has seen an increase in civil war and low-scale conflicts rather than massive international wars. This statement remains contested, and some scholars, like Mary Kaldor, argue that what we are witnessing is not, in fact, the change from international wars to low-scale civil war, but rather a surge in a new type of international wars: "new wars". 1

The theory of "new and old wars" touches on the subject of organised violence, and its main authority, Mary Kaldor, argues that at the end of the Cold War a new type of warfare, "new wars", developed along with social and economic changes under the impact of globalisation. "New wars" are characterised by disintegration of states caused by societal and economic factors such as a rise in refugees, decline in economic factors, preponderance of human rights violations, rise in privately funded armies and various paramilitary groups, criminalisation of the state (where the state is involved in illegal trade and/or exploitation of neighbouring states), and the loss of a monopoly in the use of force. Furthermore, social factors such as ethnicity and religion have become more important in "new wars," while the eminence of political ideologies such as socialism and communism has declined. This fundamental change in warfare helps us re-evaluate conflict analysis and re-open fundamental questions about International Relations which are central to our understanding of modern society.

In her book, New and Old War: Organised violence in a Global Eras, Mary Kaldor introduces the war in Bosnia Herzegovina that took place between 1992 and 1995 as her central case. On the Bosnian case she worked extensively both as a researcher and an activist. Her case-study analysis of the Bosnian war remains the core of her "new wars and old wars" theory. Here I will offer a new case-study analysis on a new case, in order to test Mary Kaldor's theory of "new and old wars". The case I analyse is that of the wars of the Democratic Republic of the Congo from 1996-2003.

The Democratic Republic of the Congo (DRC) has seen two large scale wars in modern times. The first war, known as the First Congo War, was, in some aspects, a costly ramification from

\footnotetext{
${ }^{1}$ In this thesis, the theory of "new wars" will be referred to as the theory of "new wars" or theory of "new and old wars". I am inclined to refer only to "new wars" since this is the theory's focal point; nevertheless, the theory is also known as "new and old wars".
} 
the 1994 Rwandan genocide and an attempt to replace the governmental structures in the DRC. The war ended in mid-1997 when a new transitional government was put into place. Directly following the First Congo War came the Second Congo War in 1998. After five years, the Second Congo War ended officially with the Pretoria Peace Agreement that came into effect in June 2003. The Second Congo War was an international conflict in the DRC where no fewer than nine countries took part, directly or via proxy. With its jumble of human rights violations, population displacement, mass killings, and economical exploitation, the Second Congo War remains one of the more complex conflicts of modern times.

Attempts to analyse the Congo Wars themselves remain scarce and seem to take a backseat to other inquiries, although several studies have been conducted by scholars such as Filip Reyntjens. Thomas Turner, and John Clark to understand the logic and reasoning behind the wars. My intention is not to analyse why the wars took place, but rather to analyse the wars themselves and apply to the subject a theory of "new wars". My research revolves around the idea of a new type of warfare, and my research questions are: (1) in the two Congo Wars 19962003, who were the main victims?, (2) who were the main actors?, (2) what was to be gained?, and (3) how was it financed? This research will demonstrate the fundamentals of the Congo Wars and show that the Bosnian War between 1992 and 1995 was not the only exception to what is considered the character of contemporary warfare. I attempt to understand warfareparticularly African warfare-on a deep level and to make sense of the vast amounts of information and analyses available on the Congo Wars. In my analysis of the Congo Wars, I apply the method of a single-case study, which enables me to conduct an in-depth analysis of a singular case and analyse each individual aspects of the case. Here, I will focus on the central arguments of Kaldor's theory, and analyse the actors, aims, economic aspects, and victims of the two Congo Wars to determine whether the two wars correspond to the idea of "new wars".

This research on the Congo Wars can prove vital in the furtherance of the "new and old wars" theory, as it analyses the nature of the two wars. Understanding the nature of warfare can further our understanding of successful resolutions to modern wars. Such an understanding can also help us develop new international laws, since the current ones pertain primarily to largescale, out-dated, rarely seen wars in which national armies fight decisive battles targeting enemy soldiers. As warfare develops with globalisation and modernity, resolutions, and reactions to said warfare must develop as well. 
The structure of the thesis is as follows: in chapter two, I present the theoretical framework, which lays out the assumptions, conclusions, and logics of the theory that is used to answer the research questions. The framework covers Mary Kaldor's theory of "new and old wars" along with criticism and a discussion on alternative theoretical approaches. In chapter three, I present and discuss the methodology. In chapter four, I analyse the two Congo Wars where I apply the methodology on the literature and test the theory. In chapter five, I offer general discussions on the findings along with ideas and thoughts on further research. I conclude the thesis with a summary of my analysis and discussions. 


\section{Theoretical Framework}

In recent years, many scholars, like Martin Shaw, Mary Kaldor \& Edward Newman have remarked on what they describe as the decline of war in the twenty-first century. What these studies show is what Mary Kaldor calls a decline in "old wars" - that is, a decline in interstate wars involving two or more states in which a large battle is the decisive encounter. The "new wars" developed as the "old wars" declined. Kaldor uses the term "new" to draw the attention of policymakers and make them address the need for new approaches in conflict analysis. "New wars" involve a blurred divide between war, crime, and large-scale human rights violations. In this chapter, I introduce Mary Kaldor's theory of "new and old wars". Since the aim of this thesis is to test the theory, I must lay out its structure, logic, and arguments before proceeding. I emphasize Kaldor's main arguments of "new wars", i.e. the change in actors, "new war economy", the different goals, and different victims of "new wars". Finally, the critique/limits to the theory will be addressed, and my case study analysis will be placed within context of the theory. I end the chapter with some discussion of other research made on my case.

Mary Kaldor's central argument is that during the 1990s, a new type of organised violence and warfare developed under the guise of globalisation. The fundamentals of the "new and old wars" theory are the disintegration of states and changes in social and economic relations. The theory of "new and old wars" is not the work of only one author, even though this thesis mainly addresses Kaldor's work. Various scholars concur that the main aspects of warfare have changed in the post-Cold War era, and many have studied a number of social, political, and economic factors in attempting to analyse this change. These scholars do not address the change of war in the same manner as Kaldor, but certain patterns can be found in most "new wars" theories. Mary Kaldor's work is ground breaking, hence my decision to test her theory in my research. Kaldor's work touches on subjects of conflict studies that are relatively ignored today but still central in the understanding and studies of social sciences. Her theory can further our understanding of contemporary warfare and help future policy makers understand the very nature of war.

\section{1 "Old wars"}

To better understand the "new war" theory, one must understand the Kaldorian concept of "conventional war" or "old war". Kaldor's explanation of "old war" is based on the Clausewitzian notion that war is made up of three levels; the state, the army and the people. 
Wars were fought for a definable political end; mainly the state interest. "Conventional war" or "old war" was characterized by rules, it was a socially sanctioned activity, and was organized and justified. In "old wars" there existed clear distinctions between the public and private, the internal and external, the economic and political, the civil and the military, the legitimate and illegitimate bearers of arms, and, finally, between war and peace (Kaldor 2012: 15-22).

Modern war developed in the nineteenth century as characterised by large wars between states with a strong emphasis on scale and army mobility. Such warfare was perfected with the Napoleonic wars at the beginning of the nineteenth century. Codification of the laws of war begin in the mid-nineteenth century with the Declaration of Paris (1856). The Geneva Convention (1864), the Saint Petersburg Declaration (1868), the Hague Conferences (1899 and 1907), and the London Conference (1908) all then contributed to what is known today as international law, mainly concerning the conduct of war, e.g., the treatment of prisoners, civilians, and the wounded. There were drastic advances in technology as well, which were applied to the military field. Modern wars, as they developed in the nineteenth century, were legitimised, international, extreme, and led to increasing levels of destructiveness (Kaldor 2012: 16-26; Van Creveld 1991: 35-42).

In the twentieth century, the distinction between the military and the civilian, the combatants, and the criminals, started to break down. Civilian and economic targets were considered legitimate military targets, and the bombing of civilians was considered a "military necessity". The two world wars in the first half of the twentieth century were similar to wars between states at the end of the nineteenth century. The idea of rational wars was at its height in the two world wars, in World War I by encouraging people to fight for their king and country and in World War II to fight the evil the Nazis represented. The idea that war was an undesirable solution to international disputes began to gain acceptance after World War I. This idea was reinforced after World War II and codified in the United Nations Charter. Today, the use of force against another state is only accepted in self-defence or if sanctioned by the international community (Kaldor 2012: 26; United Nations Charter article 39-51, 1945).

The irregular and informal wars of the second half of the twentieth century are then seen as the forerunners to the new forms of warfare. The end point of the "rationalised" wars can be seen as the development of weapons of mass destruction, in particular nuclear weapons, but their usage could never be rationally justified (Kaldor 2012: 27-31). "Old wars" had reached their 
all-time high, and in the end of the twentieth century, we can see the emergence of "new wars", which I will address in the next chapter.

\section{2 "New wars"}

"New wars", or wars in the post-Cold War era, differ from "old wars" in four distinct ways. Firstly, they are characterised by new actors - mainly non-state actors, paramilitary groups, local warlords, criminal gangs, and mercenary groups - which challenge the authority and the monopoly of violence of the state. Secondly, the "new wars" show a significant increase in civilian casualties - innocent civilians have moved from "casualties of war" to the main targets of the violence. Thirdly, the goals of the actors involved have changed from ideological and/or geopolitical interest to economic and various social factions. Lastly, there is what Kaldor refers to as "new wars economy" wherein the "new wars" are financed and sustained by illegal trade, looting and exploitation in weapons, and distribution of illegal drugs (Kaldor 2012: 1). These "new wars" are "globalised, decentralised and with a low participation rate as well as a high unemployment rate" (Kaldor 2012: 1). These components make up the core of the "new war" theory and furthermore, are the four units I will look for when conducting my case study analysis. This chapter is built up on Kaldor's theory, and what follows is a critique on her work and the theory of "new and old wars" along with a discussion on the development of the theory.

\subsubsection{Globalisation}

Globalisation plays a significant role in Kaldor's theory. The core aspects of "new wars" are in some ways due to globalisation, a new term in social sciences. However, it can be argued that the process of globalisation, has been around for longer, exemplified by the form of capitalism which was forged in the manner of a world-system in the wake of the development of the modern world (Wallerstein 1974).

What is new in this form of globalisation is the information and communications technology. Firstly, global communication and information have become ubiquitous. With such ready availability, awareness of violent conflicts has risen. This has, in turn, resulted in increased involvement of journalists, international agencies, international non-governmental organisations, and military advisers and troops in global affairs. Further, globalisation involves the trans-nationalisation of governance and has affected social structures as well, as can be seen in the near disappearance of the "working class". In our globalised society, manufacturers 
employ low-cost workers such as immigrants or women, or else outsource production to lowwage countries like India. There is an emerging form of "cultural classification", i.e. the way in which people identify themselves. Some see themselves as part of a global community while others identify not with humanity as a whole, but with a certain religious faction or national community. Moreover, globalisation has often fuelled violent conflicts in contemporary times, catalysing the emergence of greedy paramilitary groups that seek state power and access to resources (Kaldor, 2012, 73-78).

"New wars" are associated with failed or failing states under the impact of globalisation, which can be characterised by three elements: endogenous problems, an internal collapse of law and order, and, no domestic bodies capable of representing the state at the international level (Thürer, 1999, 731-761). According to Global Policy Forum:

Failed states can no longer perform basic functions such as education, security, or governance, usually due to fractious violence or extreme poverty. Within this power vacuum, people fall victim to competing factions and crime, and sometimes the United Nations or neighbouring states intervene to prevent a humanitarian disaster. However, states fail not only because of internal factors. Foreign governments can also knowingly destabilize a state by fuelling ethnic warfare or supporting rebel forces, causing it to collapse (Global Policy Forum, 2017: 1).

Failed states are commonly defined in opposition to the successful states that are presumed to be the norm in International Relations. (Brooks 2005: 1160-1162). The "new and old wars" theory developed under the umbrella term of globalisation. The idea of globalisation is essential to recognise the impact that the process has on International Relations. Globalisation undermines and radically alters the politics and general character of "old war".

\subsubsection{New actors, aims, victims and economy}

"New wars" do comprise traditional actors such national armies, to some scale, but they are also populated by non-state actors and other groups participating. Kaldor identifies five main categories of fighting units; the decaying regular armed forces, usually state actor; paramilitary groups; self-defence units; foreign mercenaries; and regular foreign troops under international authority. Each of these groups will now be discussed in some detail. 
Regular armed forces, as seen in wars of the twentieth century, are in decay due to cuts in military spending by governments ${ }^{2}$ and inadequate training. Furthermore, soldiers in many African areas no longer receive any training or regular pay. These factors spur the increase of the next unit of forces. Paramilitary groups are the most common fighting units in "new wars". These are autonomous groups of armed men often centred on an individual leader. They frequently include unemployed young men recruited to a militia, given proper training, and offered a salary. These groups can be understood as the new "regular armed forces", mainly due to the fact that they are often established by the government in order to distance themselves from the more extreme manifestations of violence. Paramilitary groups are regularly associated with extremist parties or political factions. They can include criminals, and even child soldiers, and they rarely wear uniforms although they often sport distinctive clothing or signs. Selfdefence units are volunteers who try to defend their localities. They are difficult to sustain and often end up joining or cooperating with other armed groups, thereby getting sucked into the conflict. Foreign mercenaries include both individuals on contract and mercenary bands. In this unit, private security companies are a growing phenomenon, often comprised of retired soldiers who are hired by governments and by multi-national companies. Regular foreign troops ordinarily operate under the mandate of international organisations such as the United Nations (UN) and the North Atlantic Treaty Organisation (NATO). They are not directly involved in the war (Kaldor 2012: 96-100).

These various groups operate both autonomously and in cooperation. What appear to be armies are horizontal coalitions of breakaway units from the regular armed forces, local militia or self-defence units, criminal gangs, groups of fanatics, and hangers-on, who have negotiated partnerships, common projects, divisions of labour or spoils (Kaldor 2012: 101).

These fighting units, apart from the final category, have much in common with those involved in guerrilla warfare ${ }^{3}$. What they lack is the hierarchy and command systems that have been typical of guerrilla warfare forces. These new actors are as different as they are numerous; what they have in common is their relative lack of central command, which makes the "new wars" that much harder to end (Reno 2011: 165). "New wars" are characterised as guerrilla warfare in that they are not limited to a certain battlefield and do not require massive concentrations of

\footnotetext{
${ }^{2}$ Exception to this statement is the United States with a military budget of 597 billion dollars in 2016 (Taylor and Karklis 2016)

3 “Irregular band of armed men" unable to contribute to a traditional army (Ernest 1939: 140).
} 
armed forces. The aim is to control the population, mainly by spreading fear and hate and eliminating anyone with a dissenting opinion or distinct identity (Kaldor, 2012, 9).

In the "new wars" we do not only see a change in actors but also in victims. The traditional casualties of soldiers have almost disappeared and, according to Kaldor, victims of "new wars" are civilians targeted with what she calls "population displacement techniques"; systematic murder of those with different labels, ethnic cleansing, or genocide, and rendering a certain area uninhabitable. Available data show that the number of internationally and internally displaced people has risen dramatically in the last few decades which correlates with the idea of "population displacement" (Kaldor, 2012, 104-107). Civilians are, sometimes persecuted for their politics (Kaldor 2012: 11), often they are seen as collateral damage (Kaldor 2012: 171) or they fall victim to the fighting due to the fact that it is very hard to distinguish civilians from combatants because of the lack of uniform (Kaldor 2012: 211). In her theory, Kaldor makes two quantitative claims about the new victims of "new war". The fact of the matter is that it is difficult to report truly on casualties of "new war" when the data is inaccurate or false, and often governments only disclose deaths of combatants in battle and do not regard civilian deaths as part of that equation (Kaldor 2012: 212-213). Another fact is that in the post-Cold War era, the vast majority of deaths in conflict are civilians, and the rise of civilian deaths correlates with the rise in battles. This reality shows that the data available can prove to be false, since the civilian casualties are often omitted.

"New wars" are a mixture of war, crimes and human rights violations. The parties to a conflict very often frame what they do in political terms and in so doing, they see themselves primarily as fighting a war, which in turns legitimizes their actions (Schouten 2009). The political goals of the "new wars" relate to claims to power on the basis of seemingly traditional identities, but it would be a mistake to understand them as traditional. These goals are in fact contemporary phenomena arising from contemporary causes and displaying new characteristics. (Kaldor, $2012,71-72$ ). The goals of new wars can be defined in terms of "identity politics" which, as Kaldor explains is "the claim to control the state or bits of the state in the name of an exclusive group identified in terms of ethnicity, religion or tribe" (Kaldor, 2005, 212). This is in contrast with earlier ideas of communism or liberal nationalism which was aimed at the entire population of a particular state. This form of political mobilisation is built on past grievances and has two main sources, both connected to globalisation, and it emerges out of the insecurity associated with the process of globalisation and the advent of what can be described as the new 
contemporary economy - new forms of legal and illegal ways of making a living (Kaldor, 2012, 79-82).

Along with the identity politics there remains the question of the economic environment in which these "new wars" thrive. Kaldor introduces the new war economy as a "form of extreme globalisation" (Kaldor, 2012, 107). Economic motives and greed are important driving forces of violent conflict, but they alone cannot explain the viciousness of the "new wars". The production and sale of drugs is one of the key sources of income in many countries along with illegal trade of goods such as timber, diamonds, and oil (Kaldor, 2012, 108-113). The wareconomy can be seen as a "resource curse"; the actors in the conflict need the money to finance their fighting for the money.

\subsubsection{Summary}

New actors, new victims, new aims, new "war economy", and globalisation are the elements that comprise the "new wars" theory. This theory defines the wars in the end of the twentieth and present times and draws crucial attention to these elements. The shift from national armies to paramilitary groups and private armies, the "identity politics" that define the core aims of the actors and the systematic targeting of civilians with population displacement are the main aspects of the "new and old war" theory. Kaldor's work is ground-breaking in some respects, but some scholars have, nonetheless, identified some flaws within the theory. Below I will offer some critiques on the aspects of what Kaldor names "new war".

\subsection{Critique}

The theory of "new and old war" has met criticism for several reasons. Here I will address the main critiques put forth by Martin Shaw, John Mueller, Stathis Kalyvas, M.L.R. Smith, Herfried Münkler, and Edward Newman. Critiques of the theory are important in order to put my own study in a fuller, more refined context. The main arguments against Kaldor's theory concern whether the "new wars" are "new"; whether the "new wars" are in fact "wars" or simply crimes; and whether the data support the claims about new wars.

\subsubsection{Are "new wars", "war”?}

Martin Shaw (2003) argues that "new wars" are not in fact wars; instead, they are merely criminal actions performed by criminals with no political goal in mind, i.e., they are in 
Kaldorian understanding "old wars". (Shaw, 2003; Shaw 2001). A similar argument is made by John Mueller (2004), who argues that what we have today are only remnants of war and that "new wars" are not what we commonly understand as wars, but, rather private criminal acts between paramilitary groups and various non-state actors (Mueller, 2004). Furthermore, Henderson and Singer (2002) suggest that the term "new wars" is a "typological hodgepodge" of armed conflicts, i.e. various interstate, extra-state, and intrastate wars squeezed into a single category (Henderson \& Singer, 2002: 165-190). In other words, there is nothing "new" about "new wars". There is nothing warlike about them as they consist merely of anarchy, violence, and crime.

M.L.R. Smith (2003) agrees with this criticism and in fact, what we are seeing in contemporary conflicts and "new wars" across the world is not a new phenomenon but can be understood within the traditional framework of war. Here, wars are a product of a power struggle, and even though wars are traditional, "All wars are unique to their time and place. They all have distinctive origins and directions. Because they are multifarious they defy categorisation and cannot be reduced and subsumed under general labels..." (Smith 2003: 37). Smith takes a different stand on the "new war" theory and believes that wars of the twenty-first century can and should be understood as traditional, Clausewitzian wars and that all new developments in warfare are in fact non-existent; all wars, new and old, are in their essence power struggles (Smith 2003: 20-25).

Finally, Herfried Münkler (2003) agrees with Smith that wars in the twenty-first century are ever changing but still very much in sync with Clausewitzian thinking. "From Clausewitz' perspective, the factor that brings about the most far-reaching and momentous changes in the forms taken by war is the interdependence between elemental violence, strategic creativity and political rationality" (Münkler 2003: 7). War does not follow a recipe for development; it is subject to far more complex factors. According to Münkler, the future of warfare will be in high-tech and/or low-tech weapons, not national armies or various non-state actors. Furthermore, Münkler assumes that the development of warfare exists in a loop, and we will soon see warfare that resembles the wars fought from the fourteenth to the seventeenth century (Münkler 2003: 8-21).

As has been noted, "new wars" can be described in several ways, and not using the term "war" is convenient and simple for policymakers and the international community. Not defining "new 
wars" as wars excludes them from International Humanitarian Law (IHL) or jus in bello. These international humanitarian laws and laws of armed conflict were set out in the United Nations Charter of 1945, and they regulate the conduct of parties engaged in armed conflict. IHL seeks to minimize suffering "by protecting and assisting all victims of armed conflict to the greatest extent possible" (International Committee of the Red Cross 2015: 8). The legality of the use of armed forces in International Relations is determined solely under jus ad bellum (Latin "right to war"), and some use of force can be rationalised within a legal framework. If "new war" is not "war", it does fall under the legal framework of armed conflict nor the jurisdiction of IHL, and therefore does not require military or political response. The reason why it is crucial to classify the conflicts and wars of the post-Cold War era as war relates to the importance of a political response. The "new wars" are political and require a political solution (Kaldor 2013: $6)$.

I do agree with Münkler that all wars are ever-changing in some aspects. Every conflict and war should be treated as unique, as Smith points out, and all wars are in some sense "new" insofar as there are certain types of wars we have not seen before, as when the warring actors (militias, paramilitary groups, non-state actors in general) are new in each conflict. Every war, as Münkler states, has its own way of deploying means and is in that sense ever changing. What Kaldor tries to do is to underscore the importance of further developing the policies regarding warfare in order to resolve the conflicts effectively. Developing policies requires developing attendant theories. One can argue that what Smith and Münkler view as the future of wars and warfare is overly simplistic and does not correlate with reality. "New wars" are complex in nature, the parties to the conflict are multiple and difficult to distinguish, and the means of funding the war often become the reason for continued fighting.

\subsubsection{The question of the evidence}

All analyses need reliable and substantial data beneficial to the research in question. In social sciences, there has been a long-standing debate concerning the quality of quantitative and qualitative research. The critique of Kaldor, unsurprisingly, revolves around her choice of data; the "new wars" theory relies on qualitative rather than quantitative research. Kaldor has used some quantitative data, mainly to highlight the declining number of armed conflicts and the change in victims, showing that the victims of conflict in "new wars" are almost all civilians, that we have seen a decline in interstate conflicts, and that intrastate conflicts have increased 
(Kaldor 2013: 7; Figure 1). Scholars' definitions and documentations of civil war differ and therefore, "different analyses may present different results on conflict trends" (Newman 2004: 180). E.g., the Uppsala Conflict Data Program ${ }^{4}$ refutes the claim that there has been a linear decrease in the number of interstate wars and an increase in the number of intrastate wars (Melander et al., 2016).

"New war" theory relies primarily on qualitative data, which Kaldor uses to evade some of the drawbacks of existing quantitative data laden with "old war" assumptions. Kaldor points out that "for violence to be counted as war [and included in the database used in quantitative research], there has to be a state involved at least on one side and there have to be a certain number of battle deaths" (Kaldor 2013: 7). One of the main arguments of the "new war" theory concerns the difficulty of distinguishing external from internal and non-state from state actors. The data primarily measure the decline in traditional "old wars" and the decline in the numbers killed in battle, which is consistent with Kaldor's argument (Kaldor 2013: 8). This criticism of the data is in essence a catch-22 that will not be resolved until the data reflect broader, more versatile aspects of warfare, with or without the state as an actor. Data analysis in conflict and war is and will remain incredibly complex.

\subsubsection{Are "new wars" new?}

Edward Newman (2004) draws on the historical data of "new wars" and argues that the theory does not address the historical significance of the data of wars in the nineteenth and twentieth century. He claims that all "new" factors in the "new wars" have been present in wars of the twentieth century, and even in wars waged in the Congo in the twentieth century, e.g. the Congo Independence War of 1960 (Newman 2004: 179). He argues that "presence or absence of certain factors is best explained by the peculiarities of specific conflicts rather than linear historical changes." (Newman 2004: 180). According to Newman, there is nothing "new" about "new wars" and that the only thing that has changed is that scholars and policymakers now focus more on the social and economic factors of wars which, he believes, leads them to wrongly conclude that warfare, not scholarship, has changed. More importantly, advances in communication and media have brought the harsh but unchanged realities of civil war to public attention (Newman 2004: 179).

\footnotetext{
${ }^{4}$ Established in the mid-1980s and continuously collects data on armed conflicts. The data is collected on an annual basis and definitions of armed conflict are designed to pick up the same phenomenon across time and space (Online at: http://www.pcr.uu.se/research/ucdp/program_overview/about_ucdp/).
} 
Stathis Kalyvas (2001) points out that there is only "old civil war" and "new civil war" and that the main goal of the "new civil war" is economic gain; it is in its essence greed (Kalyvas 2001: 102-103). Kalyvas emphasises that detailed analysis is required and "we need to specify the key mechanisms carefully, identify the relevant empirical indicators and collect appropriate and accurate data." (Kalyvas 2001: 118). Kalyvas states that the data collected when researching the "new civil war" is more often than not biased and incomplete (Kalyvas 2001: 109).

Mary Kaldor recognises a power vacuum that was created after the Cold War, and it would be foolish not to emphasise the importance of the end of the Cold War. Kaldor is not arguing that all "new wars" are new, and she does agree with Newman (2004) that elements of "old war" are definitely part of "new war". Kaldor does not refer to all earlier wars when she talks about "old war", but merely a specific style of war, and an outdated one. The idea is not to make a new definition of war and say that all wars after the Cold War are that particular type of war. Rather, the reason for the "new war" theory is to "...change the way policy makers and policy shapers perceived these conflicts [and]... emphasise the growing illegitimacy of war" (Kaldor 2012: 203).

\subsubsection{Summary}

Kaldor's critiques seem primarily concerned with her loose definition of what constitutes "new wars". Under her vague, inconclusive definition, almost all state to non-state conflict can be seen as modes of "new war". Although no major world wars have occurred since the Cold War, wars between states do still occur. What Kaldor calls "new wars" can indeed be understood in some ways not as a new type of wars, but as crimes or even "old wars". Though attendant data is scare and unreliable, all of these scholars nonetheless agree that Kaldor's theory is essential, and her theory can in many ways be seen as the groundwork for continuing the analysis of warfare in the twenty-first century. Kaldor has addressed all of these criticisms convincingly and proven that her theory of "new and old wars" helps us re-evaluate all modes of warfare in order to better understand political thought, International Relations, and modern society.

\subsection{Alternative theoretical approaches}

The Congo Wars can by analysed on different levels. Recent studies of the Congo Wars provide us with detailed narratives of how the wars began and numerous causes to the two wars. Some 
scholars wish to contextualise the Congo Wars within a continental trend (Young 2002: 1331); whilst others are inclined to theorise the Congo Wars in order to make sense of them both in a historical perspective and within the international community. I will offer some discussion on constructivist, neoclassical realist and rational choice thought in order to deepen the understanding of the cause of the Congo Wars. Here the intention is to broaden the view so we can see the value of other theories and what they can add to the case in question.

Rational choice places all emphasis on actors in International Relations. Actors, individual or on a state-level, behave rationally if they are goal-oriented, reflective (evaluative), and consistent across time and different choice situations. Any social structure is a "chain" of individual, interconnected actions, and political outcomes are the result of interdependent individual actions based on preferences and knowledge of individuals. Some authors dealing with conflict in the Great Lakes region (Burundi, the DRC, Kenya, Rwanda, Tanzania, and Uganda; see Map 3 in Appendix D) argue for the rational behaviour of actors. In his discussion on the Congo Wars, Thomas Turner (2007) refers to Rwanda and Uganda as though they were rational actors with a coherent set of interests and perceptions. Rather than emphasising the failure of the DRC as a cause of the war, Turner maintains that the rational choice of actors is crucial to understanding how and why they pursue their own perceived interests during the Congo Wars. There are several personal interests which could motivate individuals to pursue war, for instance, "economic interests", since there is little doubt that most if not all actors in the Congo Wars participated in the looting of the DRC. Stating that the Congo Wars occurred solely due to economic factors, however, vastly reduces the complexity of the wars. Indeed, Vlassenroot and Raeymaekers (2004) argue that the Congo Wars cannot be understood purely through economic factors because there are other key reasons such as security in play. Although they do not abandon the rational choice explanation, they claim that the Congo Wars must be explained with reference to the ways in which conflict "has created a situation where the rational pursuit of individual livelihood ends up reproducing the irrational phenomenon of war" (Vlasseonrrot \& Raeymaekers 2004: 13). Some scholars argue for rational behaviour and claim that the responses of the neighbours and international actors are rational in a setting in which very weak states have become unsustainable. However, Turner points out that there are certain deviations from the rational choice theory in the case of the Congo Wars, whereas some actions cannot be explained with rational choice, such as evident deviations from state-level rational behaviour which can be seen in the behaviour of the Congolese government (Turner 2007: 15-16). 
Antithetical to rational choice is constructivism, where actors, state or individual, are socially constructed, along with society itself. The notion is that norms, ideas, values, and beliefs form what is known as the social world. Within this social world are social structures with three main elements: shared knowledge, material resources, and known practices. Social structures exist only in social practices and are defined, in part, by shared understandings or knowledge. Within the social structures are actors who follow a "logic of appropriateness" and seek validation and legitimation through the socially constructed institutions. Material resources are included in the social structures where they acquire meaning through the structure of shared knowledge. (Wendt 1995: 73-74). The relationship between the different levels of observation is defined by stressing the reflexive relationship between the social construction of knowledge and the construction of social reality. Actors' identities and actions are constituted through social relations. This implies that the identities and interests of actors are not exogenously given, that is, existing before social interactions and processes.

A constructivist account can help us reach a more contextualised understanding of the Congo Wars. Constructivist studies undermine the rationalist modes of analysis, where the assumption is that states are the main actors opposing both other states and the societies they rule, and in which identities and interests are a given. John Clark (2011) refers to the constructivist framework of Nicholas Onuf, where actors are defined by continuity over relevant periods of time, which act within or against the rules in place and which are active in trying from time to time to alter the structures that have constituted them. The social structures are constituted by rules, by the practices that surround these rules, by the institutions to which these rules and practices give rise, and by related unintended consequences. These structures have overlapping "layers" and the challenge is determining which "layer" of structure is most relevant to the situation at hand. Clark identifies three different "structural layers" that seem to bear particularly on the construction of identities and interests relevant to the Congo Wars: the international legal system, international political competition among the world's current "great powers," and the "complexity of institutions, rules, and practices related to intervention and counter intervention that prevail at the regional level..." (Clark 2011: 158). Thus, all of the most relevant agents in the Congo Wars were the idiosyncratic regimes that ruled and ran African states in the interest of regime preservation. The most relative structures were those constructed at the regional level to facilitate the maintenance and security of these regimes, and the important rule to emerge out of this agent-structure dialectic was a rule of mutual non- 
intervention based on the legitimacy of the regimes whose identity the process of decolonisation constructed. (Clark 2011: 153-163).

Situated between classical theory and constructivism is neoclassical realist thought. Neoclassical realism is the latest advance in the realist tradition which combines elements of neorealism and classical realism, a combination coined by Gideon Rose in 1998. Rose categorises foreign policy in International Relations into four schools: "Innenpolitik theories, which stress the influence of domestic factors on foreign policy. The others are all variants of realism and highlight the influence of the international system on state behaviour" (Rose 1998: 146). One emphasises the systemic factors, the other mixes both state and domestic factors. The fourth school, neoclassical realism, is where the external and internal, systemic, and individual, meet and make up the foreign policy of a state (Rose, 1998: 146-147). Neoclassical realism offers insight not only into the structure of states (like constructivist thinking does), but also into the individuals within the structure. Neoclassical realism claims that the actions of a state in the international community can be explained by certain systemic variables; cognitive, distribution of power, systemic pressures, other states' intentions and/or threats, and various domestic variables such as institutions, political elites, and actors within a society; all affecting the power and freedom of action of the decision-makers within these states (Rose 1998: 146). Neoclassical realists agree with much of what Kenneth Waltz (1979) has written about the systemic level and in reality pay less attention to explaining the properties of the system. The neoclassical realist variant focuses primarily on explaining specific foreign policy decisions with key variables such as the system, individuals, and domestic and international factions. Scholars in this camp maintain that the benefits of a new, more scientific approach structural realist or neorealist theory - do not suffice. Anarchy is perceived as a permissive condition rather than an independent causal force. To analyse state behaviour, one should analyse the macro-societal factors and the preferences and configurations of individual and domestic actors. (Rose 1998: 148). The actors' actions are as important as the structures they act in, and, since foreign policy of states is complex it must be analysed through a variety of aspects. In small and/or fragile states, such as Rwanda and the DRC, individuals become more important in foreign policy decisions. This coincides with the claim and understanding in foreign policy analysis that in small and/or fragile states individual leaders or elites are particularly powerful. This remains true in postcolonial situations particularly where powerful leaders can enhance their own personal foreign policy preferences. Individuals are nevertheless pressured by domestic and systemic circumstances and constraints; i.e., they implement their 
preferred responses to domestic and systemic circumstances; circumstances such as regime security, economic prosperity, and border security issues. Individual leaders in small and/or fragile states do matter at times when the leader is unusually strong and/or the state is unusually fragile. (Hey 2003: 191-193).

Individuals wield considerable power in the Congo Wars and the demise of the DRC. Influential actors such as Mobutu Sese Seko, Laurent Kabila, and Paul Kagame (For a list of key individual actors in the Congo Wars, see Appendix $C$ ) play a vital role in the wars. The domestic influences within Rwanda, both the aftermath of the genocide and the refugee situation, can be seen as triggers to the Congo Wars. Kagame rose up as the saviour of the Rwandan people after the genocide in 1994, and it was widely thought that he could do no wrong. Although Kagame was the vice president of Rwanda throughout the wars, he was by far the key individual in Rwanda during the two wars. Pasteur Bizimungu, the president of Rwanda at the time, is relatively unheard of and seems to play no vital role in the wars or the decision-making processes. This shows that although not the subject of research in this thesis, individuals, rather than political figures, are important and play a part in the political policy making in the Congo Wars.

\subsection{The case in context}

There have been several attempts to approach the Congo Wars on a theoretical base. As noted above, scholars such as Thomas Turner, John Clark, Timothy Raeymaekers, and Koen Vlassenroot have all attempted to apply different theories to the origins and causes of the Congo Wars. The reasons behind the Congo Wars can be analysed on different levels, and no single theory appears to be more central and relevant than the others. I believe this is because the cases to be explained are extremely numerous and complex. Although constructivism, neoclassical realism, and rational choice theories are logical explanations and can be applied to the Congo wars, there are still some aspects of the Congo wars that do not fit completely in the mould of a single theory. These three approaches, perhaps put together, can effectively explain why the wars took place in context to geography, actors involved, and rationale. These attempts have all been successful in their own way, and these authors all have offered valid and explanatory reasons for the Congo Wars. What they failed to do, or simply decided not to do, was to offer an analytical perspective of the Congo Wars themselves - their dynamics and nature. 
The goal of this thesis is to examine the conflict in the Democratic Republic of Congo 19962003 and to test Mary Kaldor's theory of "new war and old war". To date, the main case or "archetypal example" used to support her theory has been the Bosnian war from 1992-1995, and I believe that adding another single-case study to her theory will strengthen its value. To understand the changes in International Relations, one must examine in detail the conflicts in question. Kaldor's theory provides an effective methodology for analysing the nature, dynamics, and social and economic aspects of the Congo Wars. In the end, what matters is not whether the theory is proven or not; the aim is to offer examples that can support the theory and make it useful to policy analysts in the near future. 


\section{Methodology}

This thesis is a single case analysis with explanatory analytical ambitions. The main emphasis is on testing Mary Kaldor's theory of "new and old wars". The case in question, the conflicts in the Democratic Republic of the Congo (DRC or DR Congo) in 1996-2003, was chosen due to its complex nature, and the curiosity and interest of the researcher. The case will also, I believe, add considerable value to the theory. The reason I choose to study only one case is that there is no need to study several cases since the goal is to test the merit and sustainability of this particular theory. Therefore, the similarities and differences between cases are irrelevant (Gustafson 2017: 3). Multiple case studies have their benefits, but with time and resources in mind the best method for testing Kaldor's theory remains the single case study. With the singlecase study, I can go deep into the case in question to satisfyingly test Kaldor's theory. I believe that this study will benefit from the in-depth analysis the single-case analysis offers as opposed to a superficial multiple case comparison. The thesis involves many observations within the case that will reduce the problem of incorrect inferences and the risk of indeterminacy (George \& Bennett 2005: 32). Besides improving our understanding of the conflict in the DRC 19962003, this thesis examines whether Kaldor's theory matches the reality of the conflict in the DRC.

In the following sections, I will discuss the qualitative method and the approaches used in this thesis. Then the researcher's impact on the research will be explicated, followed by some relevant ethical concerns. Thirdly, execution of the research and the data analysis will be explained. Lastly, the limits of the research will be addressed.

\subsection{Qualitative research}

Qualitative research is a broad term and not easily explained. It contains various methods of data collection, techniques, and philosophies and allows for an in-depth understanding of the perspective of the participants and meanings they give to events (Hennink, Hutter \& Bailey 2011: 9). Qualitative research methods currently benefit from "an almost unprecedented popularity and vitality" (Bennett \& Elman 2010: 499). This is, as Bennett and Elman suggest, due to the considerable advantages that qualitative research has to offer in studying the "complex and relatively unstructured and infrequent" (Bennett \& Elman 2007: 171) phenomena found in International Relations. One important aspect of qualitative studies 
concerns the case study methods, which can be multiple, single, within or in-between, case studies and they tend to have a strong exploratory power.

Single case studies are beneficial when seeking an analysis or interpretation of a single historical episode or case. These single case studies can be theory-guided, rather than guided by historical comparison, and can offer a generalizable analysis beyond the case in question. This approach incorporates a single-case, "single-outcome" study concerned with establishing causal inference within the case (Gerring 2006). It also provides room for more approaches, such as discourse analysis, and it may develop a distinct methodology and move away from the more traditional social scientific forms of explanation.

Through the application of multiple qualitative and/or quantitative research methods, single case studies can offer an empirically rich and holistic account of specific phenomena. This method may be appropriate for those rich and complex phenomena that benefit from deep analysis and testing, as well as those for which our reasons for understanding them and explaining are subjective, as is often with many of the ethical issues associated with International Relations. From epistemological and analytical standpoints, single case study analysis can incorporate various forms of single cases. The opportunity for generalisation lies then in using these individual case studies to test and build general causal hypotheses.

The case study method is sometimes held in low regard, mainly for its alleged lack of rigour and the bias the investigator may bring to the case analysis. The concern about the investigator's bias is a valid one; however, as Bent Flyvberg (2006: 237) suggests, the investigator conducting a case study contains no greater bias toward verification here than she/he does in other methods of analysis. The second concern revolves around the question of scientific generalisation. This is again, a valid criticism, and it may well be that theories that pass a single case study test require rare antecedent conditions and therefore have little explanatory range. A third and final concern is that case studies have become a synonym for freeform analysis in which "anything goes". The absence of and sometimes disregard for systematic procedures in case study research is what Robert Yin (2009) sees as the greatest potential drawback of this method due to its relative absence of methodological guidelines (Yin 2009: 14-16). This criticism may seem somewhat unwarranted, and in fact many contemporary case study practitioners representing and studying various strands of International Relations theory have increasingly sought to clarify and develop their methodological techniques and 
epistemological grounding when conducting case study analysis (Bennett and Elman 2010:499-500). There are ways to avoid these faults of case study research, e.g. with valid, peer reviewed and original literature and sources. If the investigator is aware of his/her bias regarding the case in question, he/she need not be concerned about bias in the results.

In this research thesis, I apply one method of research; within-case study analysis. This method, I believe, is the most beneficial to the present research, as explicated above. To avoid all bias, I will first and foremost refrain from implying that there is a single right answer or claiming that I can maintain a neutral stance. The next section is dedicated to the discussion on withincase analysis.

\subsubsection{Within-case analysis}

The case study method is an important method of research in International Relations for a variety of reasons (Bennett \& Elman 2007: 171). The method has been used to contribute to the knowledge of individuals, groups, and organisations, and is used in various fields of social sciences such as anthropology, political science, and psychology (Yin 2009: 4). There are several types of case studies. They can include single and multiple case studies, use withincase or between-case analysis, and rely on different types of sources. (Yin 2009: 16-25).

I employ a within-case analysis, which is, as understood in John Gerring's definition, "[an]... in-depth study of a single unit... where the scholar's aim is to elucidate features of a larger class of similar phenomena" (Gerring 2004: 341). I choose this method for several reasons; my goal is to add value to an existing theory and with that goal, I find that the within-case analysis is the best approach. As Stephen van Evera puts it,

Most theories of war are best tested by case-study methods because the international historical record of pre-war politics and diplomacy, which serves our data, usually lends itself better to deep study of a few cases than to exploration of many cases (van Evera 1997: 30).

Within-case analysis will offer an in-depth exploration of the case in question in order to discern the patterns that are revealed and see if they support, rebut, or expand Kaldor's theory. The most common mode of analysis is "comparing how the patterns evident in the case data fit with those predicted in theory or literature..." (Paterson 2010: 971). The within-case analysis can reveal details and elements that may be otherwise overlooked and can lead the 
researcher to new insights and provoke new questions (Paterson 2010: 972). Case study analyses face limitations, as do all qualitative and quantitative research methods. Any weakness of a particular method can be mitigated by situating it within a broader mixed-method research strategy where the researcher remains conscious of and transparent about he/she may bring to the research and vigilant about such biases in the literature and sources as well. Whether or not a single case study moves forward in this fashion, the method does have a great deal to offer to the study of International Relations.

\subsection{Significance/Relevance}

This case study could be the groundwork for further multiple-case study analysis regarding the Congo Wars (Yin 2009: 46-60). The within-case analysis offers an emergence of the case's patterns which can then lead to a new multiple-case study to locate general themes and patterns. Furthermore, it can provoke further within-case analyses in other cases in order to further develop, validate, or refute the findings of the research of within-case analysis (Paterson 2010: 971). Several recent studies on the Congo Wars provide a detailed narrative of how the wars began and several explanations as to why. At present, however, there is little research and analysis on how the Congo Wars were conducted, which is why I chose to study this case. In speaking with fellow students and individuals outside of academia in my home country, I found little to no knowledge of these wars, even though the war that started in 1998 has been named "The Great African War". I believe that further studies into African warfare are needed, and I hope that this case analysis will perhaps add some value to the theory of "new and old wars" and enhance its relevance to the domain of International Relations and policy making.

\subsection{Ethical issues}

Single-case studies have historically raised some ethical concerns, namely in the form of bias. If the researcher is unaware of his/her own biases and ideas, this can become problematic and compromise the findings of the research. However, if the researcher positions himself/herself in the correct way, there is much less to worry about when it comes to ethical issues. In qualitative research of this variety, it is imperative that the researcher be transparent and forthcoming, since his or her biases could influence the research. Such transparency is also crucial since the interest of the researcher is likely the main reason the particular case is researched. 
My main interests within International Relations research relate to human rights and interstate and intrastate conflicts. I'm fascinated by how and why people, whether influential individuals or governments, decide to wage war against neighbouring countries or their own people. I also believe that the current policies in International Relations when it comes to war or conflict need to be developed further in order to solve the issues we face today. These are some of the reasons why I chose to conduct this research. I also feel passionate about African issues and people, and believe that my future research will pertain to this geographical region.

\subsection{Execution}

To conduct the theory testing research, I will describe the conflict in question; examine and analyse each step of the theory; and locate the main arguments of Kaldor's theory. My collected data will then be put into context to test the theory. This is known as a within-case analysis, where the aim is to explain the case in question and to delimit the scope of a particular theory (Toshkov 2016: 285). The research will involve a variety of evidence including articles and reports from organizations such as the United Nations, International Rescue Committee, and other international non-governmental organisations, as well as peer-reviewed literature. Using the method of within-case analysis, I will be able to provide a detailed understanding of the case I am researching and collect multiple data sources. I collect no original sources, but rely on secondary sources, original reports, journal articles, and peer reviewed scholarly articles. The literature and reports available on the Congo Wars are abundant, and I believe that will suffice in this research. Indeed, a major strength of the case study data collection and analysis is the use of variety of different sources of evidence. Furthermore, any case study finding is more likely to be accurate and convincing if it is based on multiple sources of evidence (Yin 2009: 97). Multiple sources are chosen primarily to add depth and rigour to the research.

\subsection{Limits to the research}

There are several limits to my study. The lack of time and resources play a role in my choosing only one case. I address this limit by choosing multiple sources, meaning that the single-case study will benefit from using several different sources. In addition to the aforementioned limits of conducting a single-case study, other limitations include time and space, since this study must be completed within a certain time span and is limited to a certain length. There is also the fact that as this is written, visits to the Democratic Republic of Congo are impossible due to the ongoing violence in the country and the dangers associated with the conflict. Therefore, 
this study must be conducted away from its original case location, and with no original data collected by the researcher, myself.

Due to the time limit, there is also the possibility that I overlook resources or choose to not include them in this research. Language barriers do play a part, I am fluent in English, Icelandic, and adequate in French, but knowledge of other languages in which information may be available is limited and could affect the scope of the study. There is also the risk of overcomplicating matters by using multiple sources of data. This can undoubtedly cause problems if done incorrectly. Therefore, my main emphasis will be on theory testing with multiple secondary sources. Bearing these limits and their proposed solutions in mind, there is no reason for this research not to prove as a success. I know that my biases could influence the research process, but I will strive to keep an open mind and consider all resources when collecting the data, which will prevent any potential ethical issues. 


\section{The Congo Wars 5}

This chapter provides an analysis on the Congo Wars and a test of the "new and old wars" theory. The examination begins with the four major components of Kaldor's theory and is followed by an analysis from the two Congo Wars. The process of the wars will not be discussed in detail and will be limited to a summary presentation. ${ }^{6}$ Each component will end with a brief deliberation about the durability of said component on the two wars in question. The aim is to determine whether Kaldor's theory of "new and old wars" holds true within the case of the Congo Wars from 1996-2003. First, there will be a discussion on the main actors of the two Congo Wars, followed by a discussion of the aims and economy with a brief analysis of the effect globalisation has had on the DRC, and, lastly, an examination of the victims targeted by the wars.

The wars in the Democratic Republic of the Congo from 1996-2003 are widely known as the singular "Congo War". Scholars also tend to split the period into two- " The First Congo War" from 1996-1997 and then the "The Second Congo War" or "The Great War of Africa" from 1998-2002, ending with the signing of the Pretoria Peace Agreement. This arrangement, I believe, will serve the research best, and I will from here on refer to the wars in the Congo as two units of war. Furthermore, I will refer to 2003 (when the last Ugandan troops evacuated the DRC) as the end point to this discussion, rather than the official date in 2002 with the signing of the peace agreement. The two wars will be referred to as the Congo Wars when addressed together, the war from 1996-1997 as the First Congo War and the war from 19982003 as the Second Congo War.

\subsection{Actors}

Several international and local actors, including local and international rebel and guerrilla forces; local and international militias; national armies; and several NGOs and humanitarian aid workers took part in the Congo Wars. Here, my intent is to discuss the armed state and nonstate actors of the wars in order apply the new actors' component of Kaldor's theory. Hence, I will discuss the most influential actors involved; for a detailed list of all recorded actors involved in the wars, see Appendix B.

\footnotetext{
${ }^{5}$ Here, the two wars will be referred to as the Congo Wars when addressed together, the war from 1996-1997 as the First Congo War, and the war from 1998-2003 as the Second Congo War.

${ }^{6}$ For important dates and key events during the wars see Timeline in Appendix A.
} 


\subsubsection{First Congo War}

Fighting for the Zaïrian/Congolese government was the national army Forces Armées Zaïroises (FAZ). About 75,000 in number, it included certain "elite units" that were considerably better off than the actual army; The Division spéciale présidentielle (DSP) which numbered about 7,000; Service d'action et de Reseignement Militaire (SARM); and the Garde civile which was about 10,000 strong. The DSP, SARM, and Garde Civile were independent sections of the army consisting of men favourable to Mobutu himself and who rallied around him, took his orders, and did not bend to the rule of the administration of the army. The FAZ were in all aspects a failed national army; politicisation, nepotism, general corruption, and embezzlement undermined true military attempts. The unpaid, untrained, and unequipped officers and soldiers were neither committed nor professional. The professional arm of the FAZ was in most respects the DSP and SARM, the soldiers that were paid and sufficiently trained (Reyntjens 2009: 108109).

Hiding within the refugees in the camps alongside the eastern border of Congo were the Interhamwe and the ex-Forcés Armées Rwandaises (ex-FAR), which consisted of about 50,000 fighters. These were mainly Hutu rebels who directed their opposition at the new Tutsidominated government of Rwanda and the Tutsis within the DRC. They quickly took control of the refugee camps within the DRC, arming civilians, controlling aid distribution, and denying humanitarian workers access to the sick, wounded, and hungry. During the First Congo War, their main supporter was Mobutu and the Zaïrian/Congolese government, since they were fighting against the Rwandan, Ugandan, and Burundian invaders. The Interhamwe and ex-FAR were formed as a government-sponsored and a government-controlled militia before the Rwandan genocide. When the government was replaced, they could be understood as a nongovernmental militia (Uppsala Conflict Data Program 2017).

The most important actor opposing the Zaïrian/Congolese government was the Alliance des Forces Démocratiques pour la Libération du Congo (AFDL). The AFDL was founded in October 1996, a few days into the First Congo War, by Congolese Tutsis, Rwandans, and Ugandans, to oust president Mobutu. The alliance consisted of four groups: Alliance démocratique des peuples (ADP) composed of ethnic Tutsi Banyamulenge; Conseil National de Resistance pour la Démocratie (CNRD), a guerrilla created in 1993 in eastern Zaïre/Congo; Mouvement Révolutionnaire pour la Libération du Zaïre (MRLZ), an opposition force in South-Kivu; and the Parti Révolution Populaire (PRP), established in 1967 by Laurent-Désiré 
Kabila. The number of troops within the AFDL was estimated at about 40,000 with Rwandan soldiers covering little more than half of that number, or approximately 20,000. Some researchers argue that AFDL was a rebel group created to cover Rwandan and Ugandan incursions into Zaïre. Others claim that the AFDL uprising only gave Rwanda and later on Uganda the opportunity to destroy the rear bases of dissident groups from their own countries. While Rwanda seems to have been involved in creating AFDL, giving military training to Banyamulenge before the uprising; other states, such as Uganda, seem to have taken the opportunity to help the rebels in order to secure their own borders (Uppsala Conflict Data Program 2017). The AFDL was held together by the Rwanda Patriotic Army ${ }^{7}$ (RPA or RDF). As the war continued, the AFDL grew in size, adding various ethnic minority groups, mostly Tutsis and other militias from eastern Congo (Thom, 1999).

Uganda and Burundi joined in the war against the opposition from the beginning, expressing similar security concerns as Rwanda, i.e., concerns about border security. These three nation states formed the Kigali-Kampala-Bujumbura axis (Reyntjens 2009: 19). Along with Uganda, Burundi, and Rwanda was the Angolan national army which was present in the conflict solely due to its fighting with União Nacional para a Independência Total de Angola (National Union for the Total Independence of Angola; UNITA). Mobutu provided sanctuary for UNITA during their fight with the Angolan government in Angola, which meant that Mobutu and subsequently the Zaïrian/Congolese government were the enemy of the Angolan government at the time (Williams 2013: 94). The South Sudanese rebel army Sudanese People's Liberation Army (SPLA) sided with the opposition (AFDL) and provided financial and moral support to the AFDL, while the Sudanese government provided aid to Mobutu's forces in order to fight back against SPLA. Child soldiers, kadogos, were also introduced by all warring parties during the First Congo War. They proved to be a cheap, effective, and extremely easily attained means of warfare.

Lastly, international actors were present in the wings - France on the side of Khartoum (Sudan) and the Rwandan Hutus, and the United States on the side of the Sudanese SPLA, Uganda,

\footnotetext{
${ }^{7}$ The RPA is now known as the Rwandan Defence Force, RDF, and is the national army of Rwanda. In the 1994 genocide, the national army of Rwanda was FAR (Forces Armées Rwandais); at the other end was the rebel group Rwandan Patriotic Front, RPF, with Paul Kagame as its leading man. When the RPF won the war in Rwanda, the RPF split into two, the RPF became the new political force in Rwanda, and the army was named Rwandan Patriotic Army, RPA. Later the name changed to its current name Rwandan Defence Force, RDF. Here, I will use the previous acronym of RDF when referring to the Rwandan national army in order to simplify matters.
} 
Rwandan Tutsis, and Luanda (Angola). In addition, present within the DRC's borders were several NGOs and international organizations such as the United Nations (UN) and the International Red Cross. During the war and the interwar years, the UN tried to conduct research on human rights abuses, massacres, and other human violations believed to be conducted by several actors during the war (Turner 2007: 5).

It is evident that in the relatively swift First Congo War, no fewer than seven countries were directly or indirectly involved in the fighting, along with several non-state actors, rebel groups, and other international organisations. What is interesting to note is that alliances that were formed in the First Congo War proved short-lived and were easily broken to form new alliances, as all international actors reasoned using the logic "the enemy of my enemy is my friend". Circumstantial alliances were very visible along two axes: on one side, France, Khartoum, Mobutu's Zaïre/Congo, the Hutu rebels, and UNITA; on the other, the United States, Eritrea, Ethiopia, the SPLA, Uganda, Rwanda, Burundi, and the MPLA. Each player represented their own agenda in the conflict, economic, political, or otherwise (Reyntjens 2009: 23-44), as will be seen in the discussion on the Second Congo War.

\subsubsection{Second Congo War}

The new, main, Zaïrian/Congolese rebel forces of the second war were Rassemblement Congolais pour la Démocratie (RCD). Masterminded in Kigali and endorsed by the Americans, the RCD functioned as a sort of proxy for the Rwandans; it was in fact the RDF and Rwanda that had invaded the Zaïre (now to be known as the Democratic Republic of the Congo; DRC) again, under the guise of RCD. The original RCD was formed on $12^{\text {th }}$ of August 1998, a few days into the second war. It consisted of several political elements opposing the new Congolese president, Laurent-Desiré Kabila. Both those who fought with the AFDL and against it in the first war were part of the new rebel movement, RCD. Aimed at ending the dictatorship (again) and promoting peace, their strength was originally estimated at 20-60,000 soldiers (Uppsala Conflict Data Program 2017).

In May 1999, the RCD split after a conflict between the movement's main backers, Rwanda, and Uganda, over the control of the city Kisangani. The two states had opposing views on the operations of the RCD. The result was two different movements, RCD-Goma with Rwandan support and RCD-Kisangani/RCD-ML/RCD-K-ML (ML for Mouvement de Liberation) with Ugandan support. Again in 2000 there was a split, this time within the RCD-Kisangani/RCD- 
$\mathrm{K}-\mathrm{ML}$, and factional fighting in the group broke out. The new movement, RCD-K-ML was shortly forced into a Ugandan arranged liberation movement called the Front de Libération du Congo (FLC). The new alliance did not work sufficiently, and the RCD-K-ML and the RCDML, which consisted of different leaders and aims, fought against each other over territory within eastern Congo. The government of the DRC supported the RCD-K-ML and provided them with military material in the internal fighting (Uppsala Conflict Data Program 2017).

RCD-National (RCD-N) was another RCD faction created in 2000 as part of the FLC. The RCD-N was based in a district between the two zones of RCD-K/RCD-ML and RCD-Goma, an extremely diamond rich region (See Map of the DRC in Appendix D). In 2001, the RCD-N joined the RCD-ML and the Mouvement pour la Libération du Congo (MLC) in an alliance, an attempt by Uganda to unify the rebel groups the state supported in the DRC. MLC was created in November 1998 with the aim of overthrowing the Kabila government. The movement was led by a Mobutu supporter and in the beginning consisted of 154 rebels. Twelve months later, it was a formidable force of over 6,000 troops. Fighting soon broke out, and the FLC split back into its former factions (Uppsala Conflict Data Program 2017). The alliance between RCD-N, RCD-ML, and MLC proved short-lived, and fighting between the three rebel groups was imminent.

In the meantime, Laurent Kabila formed a new national army, Forces Armées Congolaises (FAC) that consisted of members of the original AFDL and the previous national army, FAZ. Initially, the FAC soldiers and commanders were trained by Rwandan and Ugandan nationals, before all Rwandan and Ugandan individuals were asked to leave the DRC. During the second war, the FAC proved inadequately trained; they were weak and unable to fight the rebel movements of the opposition. Soldiers were unpaid and unfed which resulted in desertion (Uppsala Conflict Data Program 2017). The new national army was unable to fight the opposition as the second war continued.

The Angolan military joined the fighting again, this time on the side of Kabila's government. It was thought that Rwandans and Ugandans now sided with the Angolan rebel group UNITA and, that Angola sided against them (for obvious reasons) and thus fought with the DRC government forces. During the second war, Zimbabwe, Zambia, Chad, and Namibia provided soldiers and military equipment to the Congolese government. To complicate matters further, Rwandan and Burundian rebel forces fought alongside Kabila against their rebel compatriots 
and compatriots (Reyntjens 2009-222-223; Williams 2013). The United Nations peacekeeping mission in the DRC estimates force deployment in the spring of 2000 as follows: Government of DRC/Zimbabwe/Angola: around 85.000 troops; RCD-Goma/Rwanda: around 35,000 troops; and RCD-K/MLC/RCD-ML/Uganda: around 19,000 troops, amounting to a total of around 140,000 troops (Reyntjens 2009: 199). This estimate accounts only for the traditional troops that took part in the second war and does not reflect the total number of fighting bodies, which remains unknown.

The domestic and international militias and non-state actors involved in the second war are too numerous to list here. Suffice it to say that there were several different groups fighting either with the rebels or against them for territory, natural resources, population control, and so on. The most notable militias were the Maï-Maï (Mayi-Mayi or Mai Mai), a number of local militias in the Kivu regions (See Map 1 in Appendix D). They consisted of youths fighting for the protection of local villages and a prominent status in society. Some Maï-Maï groups were well-structured organisations with clear agendas and strong support, while others were more like armed gangs, followers of different warlords with very vague objectives. There was no centralised structure, but one can find a common denominator: the fight against all foreign involvement and the fight for their country's security. The Maï-Maï sided with Mobutu and the Zaïrian/Congolese government in the first war, due to the influence of high-ranking Rwandans in the AFDL. During the second war, the Maï-Maï fought against the RCD groups and were given moral and military support from the Congolese government; in 1999, four Maï-Maï leaders were awarded the rank of General in the FAC (Uppsala Conflict Data Program 2017).

International actors were again present in the second war. The United States, forever plagued with guilt and trying to make up for the tragedy that occurred in 1994, sided with Rwanda (Reyntjens 2009: 195). The presence of the UN was more apparent in the second war because the United Nations Organisation Mission in the Democratic Republic of the Congo (MONUC) was established in July 1999. According to UN resolution 1279 of November 1999, the initial plan was to observe the ceasefire, oversee the disengagement of forces, and maintain liaison with all parties of the Lusaka ceasefire agreement of $1999 .^{8}$

\footnotetext{
${ }^{8}$ MONUC's mandate has changed and has become the largest UN mission since the organisation's conception. For more details on MONUC see http://www.un.org/en/peacekeeping/missions/past/monuc/
} 
In short, during the second war, Rwanda, Uganda, and Burundi, with their RCD proxies, fought against Kabila and the Congolese government. Fighting against the rebels and for the Congolese government were the FAC and the Maï-Maï. International forces that sided with Kabila were Rwanda, Burundi, Angola, Zimbabwe, Chad, Namibia, Zambia, and Sudan. In total, nine African states took part in the Second Congo War along with countless other nations that made up the MONUC mission and played a role in the peace talks. The Second Congo War was a relative hodgepodge of states scrambling for some kind of power over populations or resources and/or searching for a peaceful resolution to the seemingly ceaseless conflict.

\section{2 "War of Liberation" and "The Great African War"}

The Congo Wars, the first one lasting from 1996-1997 and the second one from 1998-2003 (although still going on in some respect), are two of the more complex conflicts of modern times. The complexity in the wars stems from the variety of actors, aims, victims, methods, and means of financiering. The First Congo War, thought to have begun as an ethnic rebellion, ended in a swift coup d'état. The Second Congo War began with what was supposed to be another coup d'état but ended in a scramble of human rights violations, massacres, and economic exploitation.

The First Congo War had two official aims. Firstly, there was the aim of ensuring neighbouring security; Rwandans and Ugandans aimed to secure the borders between their countries and Zaire/Congo by eliminating the threat of the ex-FAR and the Interhamwe, the two main perpetrators in the Rwandan genocide. During the Rwandan genocide, an estimated 1.2 million refugees fled from Rwanda to the eastern provinces of the DRC, mostly Hutu fleeing the newly established Tutsi dominated government. Among the civilians were almost 50,000 génocidares $^{9}$ intent on regrouping and launching another attack on Rwanda (Reyntjens 2009: 47). Secondly, there was the political aim of overthrowing Mobutu Sese Seko, the notorious dictator who had ruled Congo since 1965. Mobutu was guilty of running the country into ruins, bankrupting the national treasury by stealing from the country and bribing his opponents. The general satisfaction with Mobutu was low in Zaïre/Congo at the time of the First Congo War

\footnotetext{
9 "Those who commit genocide", a term for the rebels of the Rwandan genocide hiding in the refugee camps in the DRC
} 
in 1996. Rwandans and Ugandans, along with some Zaïrian/Congolese rebels, were welcomed as "liberators" (Turner 2007: 3-5).

The starting point of the First Congo war is usually thought to be October fourth, when the Banyamulenge ${ }^{10}$ rebels attacked the village of Lemera, north of Uvira (A map of the DRC can be found in Appendix D). Rwanda was supposedly reacting to reports of one ex-FAR attack on the Banyamulenge and another major invasion on Rwanda by the ex-FAR. Though for years these were believed to be phony reasons for Rwanda's retaliation, they are now believed to be true. The ex-FAR were, according to Reyntjens (2009), planning a re-entry into Rwanda and a new war with the new government of Rwanda. By December 1996, Rwanda had accomplished some of their objectives, namely liberating the Hutu refugees in the eastern Congo from the militants and returning them to Rwanda, as well as breaking the control of the ex-FAR on one of the largest refugee camps in the eastern province of the DRC (Thom 199: 6)

By January 1997, the AFDL had broken the FAZ resistance. Ugandan presence in the First Congo War had become a reality, and reports of Ugandan troops north of Goma were more numerous. FAZ troops, desperate and discouraged, began a pillaging retreat in the direction of Kisangani, the last major military stand within the Congo army. Kisangani is the Congo's third largest city and considered the most strategic target in eastern Congo. Ex-FAZ troops had joined the rebel army, AFDL, which had grown to about 6,000 strong and included ethnic Tutsis from Congo, RDF commanders, and other Congolese rebels among their ranks. AFDL had begun pursuing the FAZ forces, ex-FAR, and the remaining refugees that decided to flee the refugee camps when the war began. At this point, the FAZ forces were unreliable, uncoordinated, and disparate. South Kivu had almost been completely destroyed, resulting in forced displacement of local militias, other anti-alliance forces, and the local populations (Thom 1999: 7-8).

The December-January period also saw an overall shift in the nature of the war on both sides. For the rebel AFDL alliance the conflict graduated from a proxy border war by Rwanda into a broader based internationally-backed, civil war to oust Mobutu and his cronies. For the government, it was becoming clear that the FAZ alone could not defeat or even contain the rebellion (Thom 1999: 9).

\footnotetext{
10 The Banyamulenge are a group of Congolese Tutsi. They emigrated from Rwanda to the DRC in the $19^{\text {th }}$ century and are mostly concentrated to the South Kivu region. They are commonly considered to be the cause of the First war with a rebellion in the eastern provinces of the DRC.
} 
Thom's definition of the First Congo War raises some questions. The tendency to define the First Congo War simply as a "Zaïre-Rwanda civil war" creates two problems: first, that a war between two (or more) states is not defined as a "civil war" but rather as an "inter-state war"11 since it moves beyond borders. The problem with this definition is that according to Small and Singer (1972), in order to be defined as an "intra-state war" these wars must result in "a minimum of 1,000 battle-related combatant fatalities within a twelve month period". Battle combatant death in the First Congo War was relatively low, hence its being defined as a "civil war", which I strongly disagree with. Secondly, the presence of several (in this case, Angola, Zambia, Zimbabwe, Eritrea, etc.) international actors with their own interests rebuffs the idea of a purely two-state war. The First Congo War was an intra-state war in all its senses and purposes.

By mid-March of 1997, FAZ and other forces fighting for the government blatantly refused to fight due to the lack of payment. Troops started to abandon their posts; FAZ troops left the town Isiro, Angolan forces deserted the town of Bafwawnde, and government defeat was becoming ever clearer to everyone, except perhaps Mobutu himself. The AFDL continued on and took the city of Kisangani with relatively little resistance in March 1997, and subsequently grew considerably in confidence and in size, seizing town after town and recruiting on their way to Kinshasa. FAZ morale was at an all-time low, and the resistance forces were virtually destroyed (Thom 1999: 8).

The final act of the war was swift but not very decisive, as the war had been over by March 1997. Peace talks between Mobutu and Kabila proved to be futile since the AFDL continued to march on to Kinshasa virtually unopposed. The opposition had won, and there was no reason to negotiate. Rebels and the AFDL were now thought of as liberators of the DRC and received generous amounts of support both from domestic and international sides. The AFDL and Kabila forces entered Kinshasa suburbs by mid-May 1997. The last main concern of both sides was to avoid, by all means necessary, a final fight for Kinshasa or a FAZ rampage in the city, since many of the FAZ troops had returned bitter and angry to Kinshasa. Knowing FAZ's history of violence and abuse against the population made the latter concern a well-founded one. This concern, however, did not come to pass, and by May 18, 1997, AFDL troops were entering the capital in vast numbers, and the war was over (Thom 1999: 10).

\footnotetext{
${ }^{11}$ Human Security Report 2010
} 
William G. Thom identified two distinct features of the First Congo War in his article CongoZaire's Civil War in the Context of Evolving Patterns of Military Conflict in Africa in the Era of Independence (1999): its proxy nature and the economic motivations. He notes that "while neighboring or regional states in Africa have occasionally supported insurgencies against local enemies, this practice has expanded in the '90s to become a recognized tool of modern Africa statecraft" (Thom 1999: 4). This holds true in the case of the First Congo War. Not only did Rwandan RDF forces offer support with military supplies, they also provided commanders and troops - a fact that suggests that the Rwandans fought in the war not with a proxy rebel force, but as a full-blown Rwandan army force. Secondly, concerning the war's economic motivations, opposition movements were chiefly interested in exploiting the conflict for material gain. The rise of economic insurgency was a consequence of soldiers not being paid or suitably compensated, and when armed insurgents emerged, they gravitated toward the locus of economic activity, whether that meant stealing, or perhaps selling concessions in territory controlled by the faction.

A foreign invasion so clearly prohibited under international law and masked as an ethnic rebellion, the First Congo War ended when Mobutu fled the country. Laurent Kabila took over the presidency, and a new government was put in place. The Rwandans and Ugandans thought that they now had a president in the DRC more favourable to them and their cause and that Kabila would swiftly "take care" of the "problem" that was the Hutus within the Rwandan refugees in the DRC - a belief that quickly proved to be false. The Congolese considered Kabila to be too favourable towards the Rwandans, a sentiment that stirred up serious antiRwandan feelings within the Congolese and pushed Kabila from the Rwandan cause. Soon after Kabila took power in the DRC, he "kindly" asked all Rwandans to vacate all high-ranking positions (and practically asked them to vacate the country), and thanked them for their services (Macpherson, 2012).

What has usually been called the "Second Congo War" was in many senses a continuation of the first war. Rwanda and Uganda had much unfinished business, and the rationale behind the launch of a new ethnic "rebellion" within the DRC was in large part similar to the one prevailing in the fall of 1996. In place of Mobutu, the new aim was to overthrow Kabila. Though the two wars differed in outcomes, they can still be treated as one and the same war or more importantly, one and the same case. The newly installed regime in Kinshasa proved 
unable or unwilling to solve the two problems that stemmed from the First Congo War - (1) the security concern of the eastern neighbours, Rwanda, and Uganda, and (2) the status and security of the Banyamulenge. (Reyntjens 1999: 241-250). Kabila grew paranoid of the local population's increasing resentment towards the Rwandan presence in the new government of the DRC. In July 1998, fearing a coup d'état, Kabila dismissed the Rwandan general and chief of staff of the FAC army, James Kabarebe, from his position among other high ranking Rwandan officials and ordered all RDF soldiers to leave Congolese territory. In response to that blatant disrespect, some Congolese Tutsi soldiers started a new offense, and with the help of RDF, the Ugandan army, Ugandan People's Defence Force (UPDF), the Burundi army, Forces armées Burundaises (FAB), and some soldiers from the ex-Forces armées Zaïroises (ex-FAZ), now focused on overthrowing president Kabila. (United Nations High Commissioner for Refugees 2010: 153-154). Rwanda and Uganda had hoped for a political pawn in the DRC that they could control, but Kabila turned out to be a troublesome ally. Within the DRC emerged a growing dissatisfaction with the Rwandan presence, which led to ethnic tensions; every Tutsi was seen as a Rwandan and every Rwandan was an occupier. It was a widely accepted idea that the overpopulated Rwandan state longed for raw materials and had its sights set on the resource-rich Kivu region.

The starting point of the Second Congo War is generally thought to be the Banyamulenge mutiny in Goma on August 2, 1998. The second war escalated quickly, and the newly founded RCD came to dominate the resource-rich eastern provinces of South Kivu and had based its operations in the city of Goma along with seizing control of the towns of Bukavu and Uvira in the Kivu regions (see Map 2 of the eastern provinces and border in Appendix D). The Rwandan forces used the massacres that Kabila was allegedly plotting against the Congolese Tutsi and Banyamulenge as a cover for occupation. A portion of north-eastern Congo was occupied by Rwandan, Ugandan, and Burundian forces. The advance of the rebels was again swift, and by the end of August 1998 the rebels were starting to advance on Kinshasa again. Kabila was, however, able to secure international aid in the last moment, and the rebel offensive was subsequently reversed. Accordingly, the beginning of the multi-faced international war had begun in the DRC. Zimbabwean forces joined the government forces in 1998 and held off a rebel advance that was closing in on Kinshasa, while Angolan units fought northward and eastward from their borders. Kabila was able to fight back solely by the grace of international intervention and aid. Angolan, Zimbabwean, Chadian, and Sudanese forces pushed back the rebels front lines from the capital of the DRC. 
In November 1998, Paul Kagame, the Vice President of Rwanda, admitted for the first time that Rwandan forces were directly assisting rebel forces in the Second Congo War for security reasons. Since the national armies that came to the aid of the government were not able to defeat the rebels, the war was beginning to escalate into direct conflict with Rwandan and Ugandan national armies. Nelson Mandela, President of South Africa, addressed the need for peace talks in order to end the violence in the DRC, and in January 1999, Rwanda, Uganda, Angola, Namibia, and Zimbabwe agreed on a ceasefire at a summit at Windhoek, the capital of Namibia. The authorities of the RCD were not invited to the summit, and the peace talks and ceasefire proved unsuccessful. There was immense tension within the RCD by that time, and in April 1999 these tensions reached a peak when leader Ernst Wamba dia Wamba moved base from Goma to Kisangani. That move divided the RCD into an RCD faction supported by Uganda and another RCD faction supported by Rwanda. Despite several attempts at reunification, the RCD would not join together again.

Pressure from the international community and diplomatic circumstances encouraged and contributed to the first ceasefire of the war, the Lusaka Ceasefire Agreement, signed in July 1999 by all warring countries except the RCD. Tensions between Rwanda and Uganda that started within the RCD reached a breaking point in August 1999 as units of the UPDF and the RDF clashed in Kisangani. Responding to rumours from Kisangani that Kabila's forces were now fully capable and prepared to retaliate against the opposition and liberate the Congolese population, the Rwandan authorities launched a large offensive and approached Kinshasa. Fighting continued between government and rebel forces and between the Ugandan and Rwandan forces on Congolese soil. Several clashes occurred throughout the country, the most notable being the heavy fighting between Uganda and Rwanda in May and June 2000. All military and diplomatic interventions and efforts made by the United Nations, African Union, and South African Development Community failed. One might doubt the seriousness of the efforts of these interventions; Rwandan authorities were frequently accused of misdeeds and severe human rights violations in the Congo, but they continued to receive substantially more international aid and support than went to the much larger Congo. Kagame was respected and admired throughout the international community for his contribution to ending the Rwandan genocide and for his countless efforts to rebuild and reunite Rwanda again after.

By 2002, the Rwandan position in the war began to worsen; many members of the Rwandan faction of the RCS had deserted or joined Kabila's government forces. Moreover, the 
Banyamulenge, the backbone and reason for the presence of military forces in the DRC, became increasingly frustrated and tired of the control from Kigali and the seemingly neverending violence. No one seemed to make any headway, and a number of the Banyamulenge mutinied, leading to more violent clashes between them and the Rwandan national army, the RDF. At the same time, the western province of the DRC was becoming more secure under the new, younger Joseph Kabila, Laurent Kabila's son. International aid resumed in the region, and inflation was brought under control by his government. During the course of the war, several unsuccessful attempts were made to end the violence. Finally, in April 2002, the Sun City Agreement was formalised. This was a framework for providing the DRC with a unified multipartite government and democratic elections without any stipulations or obligations regarding the unification of the army, which greatly weakened the effectiveness of the agreement. Consequently, the fighting reduced slightly, but did not end.

The Pretoria Agreement, signed in July 2002 by the DRC and Rwanda, marks thee formal end of the Second Congo War. The Pretoria Agreement centred on two issues: (1) withdrawing the estimated 20,000 Rwandan soldiers in the DRC and (2) rounding up the remaining ex-FAR soldiers and dismantling the Interhamwe. In September 2002, Uganda and the DRC signed the Luanda Agreement, the objective of which was to prompt Uganda to withdraw troops from Bunia in eastern DRC and to improve diplomatic relations between Uganda and the Democratic Republic of the Congo. By 2003, Rwanda and Uganda stated that they had withdrawn all their troops (which is widely thought to be false) and a new transitional government was put into place through democratic elections. (Reyntjens 2009: 194-207; Prunier 2009: 181-280; Reyntjens 1999: 241-250).

The second war took place in two phases. From August 1998 to July 1999, Rwanda, along with Uganda, Burundi, and a makeshift native rebel army (RCD), tried and failed to overthrow Kabila. That phase ended with Lusaka Peace Agreement, signed in August 1999, which brought no peace. The second phase ran from July 1999 to the end of December 2002. Rwanda and Uganda no longer tried to advance on Kinshasa, but now, with the help of local militias, controlled one-half of Congo's territory and helped themselves - on a massive scale - to the raw materials present there. Now that robbing had taken precedence over power, schisms arose within the rebellion, and there were violent confrontations in Kisangani. This turbulent phase ended with the Pretoria Peace Agreement, signed in December 2002 and set to enter into effect in June 2003. The Rwandans and Ugandans withdrew to their own countries and the United 
Nations increased its presence, thereby putting an official end to the war. Since this time, the war has been limited to the extreme eastern part of the Congo, in those areas that border directly on Uganda and Rwanda.

\subsection{Analysis}

The First Congo War introduced a variable network of state and non-state actors. It seems that state actors and national armies took little to no part in the actual fighting, and instead settled for certain non-state actors and rebel groups doing the fighting. This can be seen in the Rwandan and Ugandan support for the AFDL; rather sending in their own national army, Rwandans and Ugandans armed and trained the AFDL and sent troops to fight under the name of the AFDL. In the case of the Congolese FAZ, the DSP and Garde Civile (Civil Guard) were much better equipped to fight, and they got paid for their services. They did not answer to the FAZ nor its generals, but rather to Mobutu himself. This theme of national armies remained true in the second war as well. Again, national armies proved inadequate in fighting the rebels, which led to desertion or revolt within the fighting units. However, the fighting somehow persisted, which leads one to believe that the fighting was mainly conducted by paramilitary groups and other non-state actors.

The Congolese governmental forces (FAZ \& FAC) hardly engaged in true fighting during the Congo Wars. The Rwandan government armed and trained several rebel and guerrilla forces, and the Rwandan troops fought under the guise of aforementioned forces. The same can be said of the other various governments and state armies involved; they offered moral and military support in the form of equipment with the exception of sending in whole battalions. Foreign and domestic non-state actors continued to face each other; territorial control and management of the population were taken over by the militia and rebel groups, both domestic and from neighbouring countries (Reyntjens 2009: 223).

Mafia-like and highly speculative networks entered the fray, accompanied by private instruments for the maintenance of 'order' such as Executive Outcomes, MPRI and Ronco. The withdrawal of the state offered expanding manoeuvring space for all sorts of particular interests, including under the form of warlords, rebel movements and 'entrepreneurs of insecurity', functioning in a context of increasingly high territorial boundaries. In the pursuit of their perceived interests, these state and non-state, legal and illegal, visible and less visible actors concluded short-term and rapidly shifting alliances, thus creating a complex, moving and 
unpredictable politico-military environment (Reyntjens 2009:

143).

All the states involved supported at least one rebel group or militia, perhaps to relieve themselves from the responsibility of the attendant murdering, raping, and pillaging, and to fight without facing any consequences from the international community. The lack of training, and the fact that the soldiers were not paid, corroborates the "new and old wars" theory ideas regarding state armies. This can be seen in the desertion of the Congolese soldiers and their lack of professionalism. The DPS and the Garde Civile can be understood as the new paramilitary groups, the most common fighting units in the "new wars". The fact that alliances changed so decisively evidences the shift from old wars to new ones very clearly. It seems that the fighting during the first and second wars no longer revolved around national or state interest, but rather served immediate interests at the time.

All of the five main types of fighting units Kaldor identifies (cf. chapter 2) are present in the first and second wars. The decaying regular army, represented by the FAZ and later FAC, the paramilitary groups which included the Maï-Maï; self-defence units, which included the MaïMaï again along with several smaller, localised groups within the eastern Congo, the foreign mercenaries which, in the case of the first war was the Eritrean and Ethiopian and in the second war, Chadian, Namibian and Zimbabwean and the regular foreign troops under international authority, represented by the UN mission MONUC's peacekeeping force and other international organisations trying to provide food, medicine and general security for civilians and finally the regular foreign troops under international authority. This is interesting due to the fact that there was not direct involvement of superpowers in the Congo Wars. The US, China, France, and Russia all stayed on the sidelines, offering support through various means other than direct support.

This chapter answers the question of who fought in the Congo wars. Examining the idea of "new actors" in the theory in question (cf. chapter 2) makes clear that the development of actors involved in the First and Second Congo War is consistent with the theory. Alliances were not the only thing that changed rapidly during the wars; as Reyntjens has pointed out (2009: 199202) each party to the conflict can be understood to have separate and individual aims and personal interests. The focus on personal interests segues naturally into the idea of economic resources, as those two sections are directly linked together. This linkage will be made clearer 
in the next section, where I will discuss the various aims and economies of the warring parties and of the two wars.

\subsection{Aims and resources}

In this section I will lay out the potential aims of the actors that participated in the Congo Wars and analyse these aims to determine whether they coincide with Kaldor's ideas of the new aims of the "new wars". Kaldor's claim is that actors' aims have changed in the post-Cold War era from fighting for states' political aims to fighting for individual, ethnic, and/or personal reasons. Along with the aims comes the question of the "new war economy", i.e. how the wars are financed, including the question of looting, and pillaging villages and civilians as payment for fighting in place of regular payments from administrations. This too will be discussed in the subsequent chapter.

\subsubsection{Globalisation}

State disintegration under the impact of globalisation plays a significant role in the two Congo Wars. The DRC can be considered a failed state, in which the government in place has little to no control over its population, territories, or resources (Nienaber, nd.; Fisher 2009). The impact of globalisation can be seen in the international actors involved in the two wars, in the various NGOs, governmental armies, and other international and domestic non-state actors. The DRC has garnered much media attention in the international community due to its need for humanitarian assistance and greedy neighbouring countries trying to gain control of its vast natural resources. Media access to the wars again stems from globalisation; technological availability enhances the information available on the war. The impact of globalisation on the DRC is most evident in the new aims and "new war economy" discussed in the following sections.

\subsubsection{First Congo War}

The "Banyamulenge rebellion" is generally thought to be the cause of the First Congo War. The Banyamulenge had good reason to fear for their lives and continued stay in the DRC. According to Amnesty International, dozens of people in Uvira of South Kivu, most of them Tutsi, were arrested when "native" (i.e., Congolese Hutus) populations banded together and 
demanded the departure of the "foreigners", the Banyamulenge ${ }^{12}$ (Reyntjens 2009: 45-47). Soon after the First Congo War, the Rwandan government confessed and owned up to the rumours that the "Banyamulenge rebellion" was simply an excuse to invade the DRC (Turner 2007: 5).

AFDL's behaviour in the First Congo War was predominantly characterised by violence. The alliance had no common political program or joint political goals other than to oust Mobutu. The rebel group's psychological tactics were very effective at "announcing the imminent fall of towns while leaving an exit route open and making a serious attempt to enlist the support of the civilian population" (International Institute for Strategic Studies 2006: 438). It is widely accepted (Reyntjens 2009) that the RPA used the AFDL to conduct mass killings in the refugee camps and furthermore that the First Congo War was merely a front for Rwandan forces to invade Zaïre/Congo in order to exterminate the génocidaires.

The FAZ and Mobutu's forces had simple aims of keeping the power and overpowering the rebel forces. The states that supported Mobutu at the time each had their own personal and/or state interests and reasons for supporting Mobutu, usually connected to economic gains. For instance, Zimbabwe offered support to ensure that Mobutu would pay back his substantial debt, and Sudan sent forces to fight SPLA. The Angolan government had an aim similar to Sudan: to fight the rebel group UNITA (Williams 2013: 89-96). The Rwandans and Ugandans treated Kivu and other parts of the eastern Congo as a "free trade zone" where they illegally exported goods such as gold and coffee (Reyntjens 2009: 148). The main conflict areas, North and South Kivu, are extremely rich in resources. Border security, extermination of the Hutu rebels, maintaining power, and exploitation, along with the (secondary) political aim of overthrowing Mobutu, can be seen as the main reasons for the First Congo War.

\subsubsection{Second Congo War}

The initial aim of the second war was again to overthrow a dictator. When that aim became difficult or impossible, ${ }^{13}$ the "rebellion" quickly changed its course and focused on exploitation

\footnotetext{
12 The Banyamulenge, although settlers from the $19^{\text {th }}$ century, were always regarded as Rwandans. They never truly settled within Congolese society and kept strong ties with the Rwandans (Okowa 2007: 206).

${ }^{13}$ The Angolan military came to the rescue of Kabila and barred the rebels' access to Kinshasa. They quickly realised that the second invasion would not be as swift as the first one and that Kabila was more resourceful than Mobutu, therefore the rebels unofficially abandoned the idea of overthrowing Kabila. See Timeline in Appendix A.
} 
of Congo's natural resources and targeting certain ethnic groups, be they Hutu, Tutsi, Congolese, or Rwandan. (The Economist, 2002) Other parties to the conflict, Angola, Sudan, Zimbabwe, and now Chad and Namibia, all had the same personal reasons for fighting as in the First Congo War (cf. previous chapter).

In April 2001, a United Nations Panel of Experts launched an investigation of the known illegal exploitation of diamonds, cobalt, coltan, gold, oil, timber, people, and other lucrative resources of the Democratic Republic of the Congo. The report rightly accused Rwanda, Uganda, and Zimbabwe of systematically and intentionally exploiting Congolese resources and recommended sanctions on all the countries in question (United Nations 2001). During the course of the war, import and export levies were collected by the local militias and Rwandan and Ugandan networks. This illegal exploitation funded the wars and lined the pockets of certain high-ranking political and military individuals within the Rwandan and Ugandan armies. Toll barriers were put up, and illegal taxation was demanded of the population (Reyntjens 2009: 223). During both the first and second Congo wars, insurgents sustained themselves through illegal traffic of highly valuable resources such as diamonds, copper, and coltan. This, according to Reyntjens (2009), distinguishes contemporary insurgents from their predecessors (Young 2002: 25; Reyntjens 2009: 226). Furthermore, it can be argued that the Congolese funded their own occupation and destabilisation, since all sides of the two conflicts fought over and exploited natural resources found in the Congo (Reyntjens 2001: 312-313).

\subsection{Analysis}

The goals of the Congo Wars changed rapidly and were often too complicated to comprehend. Rather than fighting for democracy and socialism/communism, actors tended to fight for their personal and/or political interests. The idea of "identity politics" introduced by Kaldor does apply to this context, but the aims of the wars exceed Kaldor's notion. Indeed, the actors' aims seem to be far more complex than simply controlling certain areas and populations and population displacement. In the North and South Kivu areas, the extermination of Hutus and other ethnic groups and the displacement of populations are evident. Rwandans targeted Hutu refugees and other Hutu groups thought to be supporting the génocidaires; Congolese targeted Tutsi and other groups thought to be supporting the rebellion. These actions of mass killings and population displacement coincide with Kaldor's ideas of "identity politics", where one ethnic group feels threatened by the existence of another one. Civilian deaths, which were 
considered "casualties of war", are readily apparent in the Congo Wars. As Osita Afoaku states: "... it is appropriate to say that there were two different but related wars: Simultaneously, there was the war to overthrow Mobutu/Kabila, and there were the intra-opposition struggles for political and administrative control of rebel-held territories that were fuelled by economic motives" (Afoaku 2002: 120).

The wars were financed by national and individual economic motives. Fighting units turned to looting and exploiting to pay themselves and to pay for the war itself. This becomes evident when the shift in the aims takes place during the second war. The "resource curse" mentioned in a previous chapter applies here, more so in the second war, where generals and leaders started to fight for economic gain in order to keep fighting. Globalisation also played a significant role in the Congo Wars, with information flowing readily from the fighting areas and the involvement of NGOs and other international actors increasing.

These two Congo wars were a mixture of war, crimes, and human rights violations. Countries in the region were driven by personal, factional, and/or national interests, while issues related to legality of resources and human rights were disregarded and missing. The systematic killings and chosen battlegrounds in certain resource-rich regions can be understood as ways of exploiting the resources found in the area (Reyntjens 2009: 142). It can be argued that the complexity of the aims of the "new wars" adds another angle to the theory and furthermore, that these complexities and hidden agendas are more common in the post-Cold War era. Along with the new aims and the new war economy, the targeted victims have shifted from official troops to civilians. This section addresses the issues concerning the new aims aspect of "new wars" and the financiering of the wars in the research question. The statement about the targeted victims will be examined in the following chapter.

\subsection{Victims}

Along with the exploitation of Congolese resources and the complexity of the actors' aims, the mass killings of ethnic groups such as Hutus and Tutsi became one of the objectives of the actors in the Congo Wars. In this chapter, I will address the known victims of the Congo Wars. We will see that the main targets were in fact unarmed civilians and furthermore, the main sources on the numbers of victims do not agree on the death toll. Amnesty International, the 
United Nations, and the International Rescue Committee are the main sources used here and will be examined in what follows.

\subsubsection{First Congo War}

As stated earlier, it is estimated that 1.2 million refugees crossed the border into the DRC following the Rwandan genocide in 1994, along with more than 90,000 Burundian refugees following the political unrest in their country (Murison 2002: 225-226). Units of AFDL/RDF destroyed all the Rwandan, Congolese, and Burundian Hutu refugee camps set up around the eastern province of the DRC. A large number of Rwandan Hutu refugees returned to Rwanda, but several others, like the units of ex-FAR and Interhamwe, fled to the surrounding areas of the DRC, where consequently, they were pursued by the ADFL/RDF who systematically killed and destroyed the new refugee camps and barred anyone who tried to help them (Office of the High Commissioner of Human Rights 2010: 70). Forced displacements in eastern Congo left more than 750,000 people without homes or access to water, food, or medicine.

The First Congo War caused severe human suffering, especially through massacres of refugees and civilians. Mass atrocities were conducted by everyone, including by Hutu extremists (exFAR/Interhamwe) against the Tutsi population of the DRC, Burundi, and Rwanda, and by the rebel forces of AFDL/RDF against their opponents, military, or civilians. Throughout the war, the AFDL/RDF continued to pursue the Hutu refugees across the entire Congolese territory. The refugees were on a long track from east to west towards Angola, the Central African Republic, or the Republic of Congo. Many reports of violence committed by the refugees against the Congolese population and innocent civilians during their journey to safety have been attested to (Office of the High Commissioner of Human Rights 2010: 78).

Varied though the victims were, most were unarmed civilians, refugees, women, and children. Many women and young girls were gang-raped before they were killed. Violations of human rights and mass killings were conducted by all warring parties. In an attempt to hide the acts of violence and mass killings, the Congolese government requested that the Maï-Maï groups operating around Uvira, Bukavu, and Goma, dig up some of the victims' bodies and dump them in Lake Tanganyika (Office of the High Commissioner of Human Rights 2010: 74). The AFDL/RDF set up so-called checkpoints around eastern DRC to sort out the people according to their nationality, reportedly under the pretext of returning them to their home country. 
Individuals were identified as Rwandan or Burundian Hutus based on their accent, morphology, and dress, and then separated from the other people and slaughtered (Office of the High Commissioner of Human Rights 2010: 83).

Members of president Mobutu's DSP and the ex-FAR/Interhamwe killed a large number of civilians and committed acts of rape and pillage. The AFDL/RDF, as well, massacred a large number of civilians suspected of assisting the ex-FAR/Interhamwe, helping the refugees flee, or supporting Mobutu's regime (Office of the High Commissioner for Human Rights 2010; 150-153). Describing the massive and focused killing conducted during the First Congo War would be painstaking; rebel forces and their Rwandan allies made it impossible to get humanitarian aid to starving, exhausted, and sick refuges, either by blocking access to them or by relocating them out of reach of assistance. At first, the men were separated from the women and children and massacred, as reported by Amnesty International. As the war escalated, no one was spared (Reyntjens 2009: 97-98). By May 1997, the United Nations High Commission for Refugees (UNHCR) found that 246,000 refugees were unaccounted for, most likely dead. After detailed calculations, professor Kisangani N. F. Emizet arrived at total death toll of about 233,000 refugees after the First Congo War (Emizet 2000: 163-202; Reyntjens 2009: 94).

Many Congolese groups were also the victims of very grave abuse in the area controlled by the rebels, particularly in the Kivu region. The most significant massacres took place in North Kivu, and the death toll of Congolese victims could well exceed 15,000. Finally, many Burundian refugees living in South Kivu shared the fate of their Rwandan companions, arriving at a death toll of approximately 300,000 (Reyntjens 2009: 99). In contrast to the death toll of civilians and refugees, according to the UCDP the total number of FAZ soldiers dead in the First Congo War is 5,761 and AFDL soldiers 41,048. Notable but arguable, the UCDP estimates that the civilian death toll during the First Congo War to be 35,126 (Uppsala Conflict Data Program 2017).

Due to information manipulation conducted by the Rwandan and Congolese governments, the exact number of lives lost in the First Congo War will never be known. Nonetheless, it is clear that the main victims, intentional or not, were civilians and refugees unrelated to the violence. In the following section, the victims of the Second Congo War will be introduced, and we will see again that exact death numbers are difficult to find, but that the number of deaths rose dramatically in this longer lasting, far more vicious segment of the war. 


\subsubsection{Second Congo War}

Following the outbreak of the second war, President Kabila's security services and those people who were hostile to the rebellion embarked on a campaign to hunt down Tutsi, Banyamulenge, and people of Rwandan origin who ended up victims of summary executions. President Kabila called out to Congolese civilians to search for rebels and their possible accomplices. Almost a thousand civilians responded to the call from the Congolese authorities, which equipped them with weapons and used them alongside the regular forces. People of Tutsi or Rwandan origin or who bore a physical resemblance to them were the main targets. Tortures, detentions, burnings, rape, mutilations, shootings, and other forms of execution were some of the crimes conducted over the course of the second war. Again, the victims of these crimes were civilians and refugees - people suspected to either be helping the ex-FAR/Interhamwe on the one hand or the rebels on the other. During the same period, governmental security forces committed assassinations, murders, extrajudicial executions, rapes, and acts of torture directed against political opponents and ordinary civilians. (Office of the High Commissioner of Human Rights 2010: 154-171).

With many of the same actors as the first war and similar initial aims, it is no wonder that the victims of the second war were the same as well. In June 2000, the International Rescue Committee (IRC) issued a report that estimated that 1.7 million people had died in addition to the expected number in eastern $\mathrm{DRC}^{14}$ during the first two years of the conflict. The overwhelming majority of deaths were due to malnutrition and disease. Furthermore, the fighting drove hundreds of thousands of people into remote areas where they had no food, medicine, or shelter (International Rescue Committee 2000: 1-20). As of 2007, another study by the IRC put the death toll at 5.4 million and rising at 45,000 a month with an estimation of 2.2 million of those deaths occurring after the official end of the war in 2003. This leaves the death toll during the second war at 3.3 million, "but the real figure could be as low as 3 million or as high as 7.6 million" (International Rescue Committee 2008). In contrast, the UCDP places the death toll within the FAC/Congolese government at 19,111 during the years 1998-2003. The Maï-Maï lost a total of 97 soldiers during the war; the RCD and their separated groups, RCD-G, RCD-N, RCD-K-ML lost a total of 12,661 soldiers (Uppsala Conflict Data Program 2017). These numbers are part of the total of 3.3 million dead. It is interesting to note the drastic

\footnotetext{
14 The eastern DRC is defined as the provinces of North Kivu, South Kivu, Orientale, Maniema, and Katanga. See Map in Appendix D (International Rescue Committee 2000: 3).
} 
difference between soldiers and civilians dead, which shows clearly the change in warfare in the post-Cold War era.

Population displacement is again evident in the second war, with mass killings of certain ethnic groups within certain areas, especially in the North and South Kivu regions of the DRC. The main difference within the two wars being that the second war lasted longer than the first war, resulting in higher number of casualties. The second war was massive and indiscriminate, the authorities insisted from the first days of the war on the need to "find out the traitors and the enemy". Leaders first suggested that the traitors and the "enemy" were all people of Tutsi origin, but as the war escalated, all people of some farfetched Rwandan background were considered traitors and enemies (Reyntjens 2009: 198).

\subsection{Analysis}

As has been noted, the main victims of the two wars were civilians and refugees, in the form of Rwandan, Burundian, and Congolese refugees and ethnic minority groups such as Hutu, Tutsi, or Banyamulenge. The true extent of the killings and human abuses is unknown due to the information control, manipulation of media, and smoke screens put up by the AFDL and later the RCD to hide the massacres (Reyntjens 2009: 89-100). The UCDP, United Nations, and IRC all provided detailed surveys to try and determine the most accurate death toll of the two wars. Unfortunately, it remains difficult to get the Rwandan, Ugandan, and Congolese governments to cooperate with the international organisations. Although organisations differ in their assessments of the death toll, there is no doubt that there was a humanitarian crisis of staggering proportions during the Congo Wars. The two wars can be understood as wars where several massacres were conducted under the guise of an ethnic rebellion.

Population displacement techniques are evident in the Congo Wars, where systematic massacres of Hutus, Tutsis, people of Rwandan origin, and Congolese rebels are seen. Villages were raided and people were forced to evacuate or face certain death. But in reality, civilians faced death either way: on the way to a refugee camp, the victims could count on either being hunt down and killed on the way or killed in the refugee camps. This form of population displacement was an efficient way to exterminate certain ethnic groups, since ethnic groups have a tendency to stick together. Rebel forces and governmental forces simply moved into the areas where these groups where known to stay and, one way or another, removed them. The 
difference between the death toll of civilians and soldiers is staggering, showing the certainty of selected victims from all sides of the conflicts. The numbers of dead soldiers, provided by the UCDP, do support the claim that the government forces involved in the war did little to no fighting. Evidently, civilians were the main targets from all sides of the two wars, for political, religious, ethnic, or economical gain.

The systematic killing of civilians and refugees in the Congo Wars aligns with Kaldor's claim that the targeted victims of "new wars" are civilians and furthermore, answers the question of who were the victims of the Congo Wars. What remains to be seen is the exact death toll of the two wars, which also bolsters Kaldor's claim that existing data and methods of data collection on the victims of modern wars are outdated. In the colonial wars in Africa, by contrast, civilian populations often suffered "casualties of war" as the consequences of combat in their vicinity, but were seldom directly targeted. (Young 2002: 13-23). 


\section{Conclusions}

This thesis is a theoretically driven study of the Congo Wars from 1996-2003. Although much has been written about the reasons and rationale behind the two wars, existing literature proves scarce when analysing the nature and essence of the Congo Wars. My method of choice was a single case study of within-case analysis. I chose this method due to the in-depth exploration needed of the case in question. I conducted an analysis of the actors, aims, economies, and targeted victims of the two wars. These four components make up the theory of "new wars" and are central to the theory testing. The contribution of this study is in providing a theoretically informed analysis of the Congo Wars, thereby furthering the "new and old wars" theory put forth by Mary Kaldor. The history of post-Cold War warfare is narrowly focused on "lowintensity" analysis of war and warfare, and this study proves that the narrative must be widened. This study can lay the groundwork for further multiple-case study analyses on African conflict or modern conflict in general and provoke further within-case analysis on other cases.

As noted earlier, there were some limits to my research. Firstly, concerning time and space: this research needed to be completed within a certain time spam and was limited to a certain length. Secondly, there is the question of the literature and data available, since language and time play a part in my choice of resources. Due to the complex situation in the DRC today, visits and field research are not advisable and therefore, I relied on secondary sources from scholars and journalists and first hand reports from non-governmental organisations. Thirdly, my findings are limited to the accuracy of the literature, which is always a limitation in the research of wars and warfare. The refusal of governments to release certain information or cooperate with researchers always presents a problem when seeking reliable sources. This thesis measures whether the central arguments of Mary Kaldor's theory matches up to the reality of the Congo Wars, and my hope is that other scholars will now consider two core cases of the "new and old wars" theory when proving or contesting the theory. It would be worthwhile to study the specifics and perhaps someday conduct field research on the Congo Wars.

Mary Kaldor's theory of "new and old wars" states that in the last decades of the twentieth century, we see a surge of a new type of violence along with the disintegration of the state and changes in social and economic relations under the impact of globalisation. This is what Mary Kaldor calls the decline of "old wars", in which battles between state armies end the decisive 
encounter. Kaldor explores the rise of "new wars"- a new type of warfare that involves blurring the distinction between war, organised crime, and large-scale human rights violations.

Kaldor's weakness seems to be in her loose definition of what constitutes "new wars"; it is vague and inconclusive, and by her reckoning almost all state to non-state conflict can be seen as a mode of "new war". Although no major world wars have occurred in this century, wars between states do still occur and are just as much about power as before. The mode of "new wars" can indeed be seen not as war, but simply as crime or as another traditional "old war". To complicate matters, the data is scarce and unreliable. Nevertheless, Kaldor's theory is essential, and her work lays the groundwork for continuing the analysis of warfare in the twenty-first century. Kaldor has addressed all of these criticisms convincingly and proven that her theory of "new and old wars" helps us to re-evaluate all modes of warfare in order to better understand political thought, International Relations, and modern society.

There have been several attempts to understand the Congo Wars through theory-based approaches. As noted above, scholars such as Thomas Turner (2007), John Clark (2011), and Timothy Raeymaekers and Koen Vlassenroot (2004) all have attempted to apply different theories on the origins and causes of the Congo Wars. Rational choice seeks to understand the rationale behind the incentive of the Congo Wars, and states that all actors, especially Uganda and Rwanda, were indeed acting in a rational manner with regard to their security and humanitarian concerns. Constructivist thought seeks to identify the structures present within the states that took place in the Congo Wars. Furthermore, the cause for the Congo Wars can be found in the attempts of regime preservation within these states, e.g. Rwanda, Congo, and Uganda. The emphasis in constructivist thought is not on the state as the actor, as is in rational choice theory, but on the structures that reside within these states. In between theses two theories lies neoclassical realism, which states that although states matter as actors, certain key individuals play a vital role in foreign policy and International Relations. This statement can be seen as true in the Congo Wars, where important and powerful men like Paul Kagame and Laurent Kabila were highly influential within their states and/or structures.

Although constructivism, neoclassical realism, and rational choice theories are logical explanations and can be applied to the Congo wars, there are still some aspects of those wars that do not fit neatly into the mould of a single theory. Perhaps taken together, these three approaches can accurately explain why the wars took place in context to geography, actors 
involved, and rationale. However, these three approaches offer little insight into the wars themselves. While these attempts have succeeded in some regards in offering valid reasons for the Congo Wars, these authors failed to offer, or decided not to offer, an analytical perspective of the Congo Wars themselves, i.e., their dynamics and nature.

It is evident from the analysis in this thesis that the Congo Wars are indeed a case of "new wars". The actors, aims, war economy, and victims all align with Kaldor's theory of "new and old wars". The First Congo War introduced a variable network of state and non-state actors. It seems that state actors and national armies took little to no part in the actual fighting and instead allowed certain non-state actors and rebel groups to do the fighting. The goals of the Congo Wars changed rapidly and were often too complicated to comprehend. Rather than fighting for democracy and socialism/communism, actors tended to fight for their personal and/or political interests. The idea of "identity politics" introduced by Kaldor does apply in the context, but the aims of the wars are not entirely encompassed by it. The actors' aims seem to be far more complex than simply controlling certain areas and populations and population displacement. Indeed, actors' aims were far more complex than simply eliminating the enemy. The financiering of the wars was powered by national and individual economic motives. Fighting units turned to looting and exploiting to pay themselves and to pay for the war itself. As has been noted, the main victims of the two wars were civilians and refugees, but the true extent of the killings and human abuses is unknown due to the information control, manipulation of media, and smoke screens put up by the actors involved in the wars. Population displacement techniques are evident where villages were raided and people forced to evacuate or face certain death. The systematic killing of civilians and refugees in the Congo Wars coincides with the claim that the majority of targeted victims of "new wars" are in fact innocent civilians.

The idea and execution of war is dynamic and, as Jean-Baptiste Duroselle (1984) states, no satisfactory classification of war is possible. What I believe is the key in Kaldor's research and underscores the importance of her approach is not the systematic killing of civilians or the state or non-state actors involved, but rather the understanding of the nature of the war as it develops. The course of a war (Congo Wars here) often seems too complicated to comprehend and therefore gets ignored or simplistically defined as "crime" in order to easily dismiss it. What Kaldor's theory highlights, and what this case study emphasises, is the need to approach contemporary warfare in a broader manner and understand that every conflict is different though their motivating factors may appear similar. The rationale given for war and the war 
itself remain two different aspects of the same subject. Through my case study analysis of victims, actors, agendas, and economic interest, I have successfully answered the research question of whether the Congo Wars correlate with the theory of "new and old wars". The research shows that the main actors of the Congo Wars were in fact paramilitary groups and proxy fighting units, and the national armies were not technically present to fight the militias. The alliances changed along with the aims during the course of the war, as can be seen with the changing of Angolan support from the rebels' side during the first war to the government's side in the second one. The wars were largely financed by illegal trade and exploitation, where militias exported illegally some of the natural resources found in the Congo. The goal was not to exploit the country, but rather to have a means of financiering the fighting. Militias and other groups then started to fight for the natural resources they needed in order to continue fighting, something Kaldor identifies as "a resources curse". Lastly, it is evident that the main targets of the Congo Wars were civilians, who were targeted for several reasons, including their politics and/or alleged support of the "enemy". This research has enriched my understanding not only of the Congo Wars but also of wars in general. Thanks to this research, my future work will endeavour to analyse all aspects of modern warfare. 


\section{Discussions}

As stated in the Introduction, the intent here was a theoretical analysis on the Congo Wars 1996-2003: an analysis on the actors, aims, targeted victims, financiering, and economical nature of the two wars. The results have been analysed as well, and here I will offer some general discussions and thoughts in light of the results.

War in the twentieth century had common denominators, such as territorial gain, powerful national armies, and weapons of great (mass) destruction. Similarly, wars in the post-Cold War era have common denominators, such as new goals, victims, and actors. War and warfare have changed in recent times, and our understanding of such changes is vital to contemporary International Relations and, at the risk of sounding overly dramatic, to our own existence. The desire to prevent wars encourages us to further understand war. To resolve conflict, one must understand why conflicts occur. It is for this reason that scholars such as Thomas Turner and Filip Reyntjens offer an analysis of the reasons behind the Congo Wars. As we have seen, in the Second Congo War, the reasons for fighting changed in the course of the war; as well, the actors and alliances changed, which made the resolution of the war even more complicated. This, I believe, is the main reason for the "new and old war" theory: understanding the nature of contemporary warfare. "New wars" seem without cause or reason aside from chaos and murder.

Analysis of a type of war, as opposed to reasons and rationale behind a war, may at first glance seem trivial to International Relations or policy development. Nevertheless, I do believe that an understanding of twenty-first century warfare is equally as important as an understanding of why wars occur. I feel that an understanding of the actors involved, along with the reasons why they are involved, is vital in furthering successful resolutions of contemporary war. Mary Kaldor's groundbreaking work on modern warfare, coupled with other scholars' work on the subject, will prove essential in International Relations in the future. Because the wars and warfare will only become increasingly complex, an overall understanding of wars and warfare is needed.

If one compares the Congo Wars and other contemporary wars to the two World Wars, one can conclude with confidence that warfare has changed dramatically. The change does not only show up in the way wars are conducted, but also in the hatred that seems omnipresent in 
contemporary warfare. Contemporary wars such as the Congo Wars, the Rwanda genocide, and the Bosnia war are much more personal than previous wars. Contemporary warfare is not only about defeating the enemy army; it is about destroying all that the perceived enemy stands for and comes from. It is about total annihilation. What this shows us is that, even though scholars disagree in exactly where the change resides in contemporary warfare, there exists a fundamental change that must be addressed.

Critics of this thesis may argue that the research is oversimplified in service of proving the theory in question. The need for more detailed case analysis within the theory is real and, now perhaps, the scholars who feel the need to disprove the "new and old wars" theory, have two cases to examine, Kaldor's own research on the Bosnia war and now my research on the Congo Wars. I believe that the analysis above gives a compelling argument for the theory of "new wars". What this research and its findings do is further emphasise the need for a more developed approach to war in contemporary times. Clearly, the wars have changed in the postCold war era, new ideologies, or lack thereof, and goals are ever present. The research on the Congo Wars is far from over. There is still exists substantial evidence within the case that can and should be examined to further explain and understand the Congo Wars. To deepen this research and perhaps add more value and analysis to the "new and old war" theory, there are other research methods that require more time and presence in the DRC. Interviewing actors, families of victims, and civilians in participating countries such as Uganda and Rwanda could prove interesting for the case in question.

This research was sparked by my own interest in African culture. Having spent some time on the continent previously, mostly in Sub-Saharan countries, I felt the urge to understand the complexity that resides there and explore why the continent has seen more conflict than any other in this world in contemporary times. I faced the dilemma of wanting to explore a country that is at present drowning in complicated violence and conflict that seem unresolvable. My aim was to further my own understanding of the nature of the violence that has taken place in the Democratic Republic of the Congo and perhaps shed some light on it in the study of International Relations. With regard to the first aim, my own understanding of conflict in contemporary times has increased dramatically, and my interest in African culture and conflict studies has only been augmented. What my academic future holds I do not know, but I do know that it will definitely include studies and/or work in Africa. The need to explain and 
comprehend the situation in various African countries remains dire, and I wish to contribute to such understanding. 


\section{Bibliography}

Afoaku, Osita (2002): “Congo's Rebels - Their Origins, Motivations, and Strategies“, in: The African Stakes of the Congo War, edited by John F. Clark, New York: Palgrave Macmillian, 109-128.

Bennett, A. \& Elman, C. (2007): "Case Study Methods in the International Relations Subfield". Comparative Political Studies, 40 no 2: 170-195. DOI http://journals.sagepub.com/doi/abs/10.1177/0010414006296346 (accessed 15 April 2017).

Bennett, A. \& C. Elman (2010): “Case Study Methods". In The Oxford Handbook of International Relations edited by C. Reus-Smit and D. Snidal, Oxford University Press: Oxford: Oxford University Press.

Brooks, Rosa Ehrenreich (2005): "Failed States, or the State as Failure?" The University of Chicago Law Review 72, no. 4: 1159-196. http://www.jstor.org/stable/4495527 (accessed 10 May 2017).

Burke, Jason (2017): "Paul Kagame re-elected president with 99\% of vote in Rwanda election", The Guardian, available [online] at:

https://www.theguardian.com/world/2017/aug/05/paul-kagame-secures-third-term-inrwanda-presidential-election (accessed 27 August 2017).

C. Kabuya-Lumuna Sando (2002): "Laurent Désiré Kabila." Review of African Political Economy 29, no. 93/94: 616-19. http://www.jstor.org/stable/4006803 (accessed 27 August 2017).

Clark, John F. (2002): "Introduction" in The African Stakes of the Congo War edited by John F: Clark, pp: 1-13, New York: Palgrave Macmillan

Clark, John F. (2011): “A Constructivist Account of the Congo Wars" African Security 4: 147-170. DOI: 10.1080/19392206.2011.599262

Coghlan, Benjamin et al. (2008): "Mortality in the Democratic Republic of Congo: An Ongoing Crisis", 1-21, Available [online] at: https://www.rescue.org/sites/default/files/document/661/2006-7congomortalitysurvey.pdf (accessed 14 July 2010). 
Dunn, Kevin C (2002): "A survival Guide to Kinshasa: Lessons of the Father, Passed down to the Son" in The African Stakes of the Congo War edited by John F. Clark. 53-75, New York: Palgrave MacMillan.

Duroselle, Jean-Baptiste (1984): "Les guerres du siècle. Une tentative de classification", Vingtième Siècle, reuve d'histoire. 3 no.1 17-26. DOI : 10.3406/xxs.1984.1688. (accessed 3 August 2017).

Ernest, Dupuy, R. (1939): "The Nature of Guerilla Warfare." Pacific Affairs 12, no. 2: 13848. DOI:10.2307/2750798 (accessed 15 May 2017).

Emizet, Kisangani N. F. (2000): "The Massacre of Refugees in Congo: A Case of UN Peacekeeping Failure and International Law." The Journal of Modern African Studies 38, no. 2: 163-202. URL: http://www.jstor.org/stable/161648 (accessed 29 July 2017).

Fien, John. (2010): Globalisation. UNESCO, Available [online] at: http://www.unesco.org/education/tlsf/mods/theme_c/mod18.html (accessed 20 May 2017).

Fisher, Max (2009): “The World Largest Failed State: Coinciding with Hillary Clinton's trip, three experts offer insight and advice on Congo. The Atlantic, Available [online] at:

https://www.theatlantic.com/international/archive/2009/08/the-world-s-largest-failedstate/348435/_accessed 5 Aug 2017).

Flyvbjerg, B. (2006): 'Five Misunderstandings About Case-Study Research', Qualitative Inquiry, 12, 2, 219-245.

George, Alexander L., \& Andrew Bennett (2005): Case studies and Theory Development in the Social Sciences, MIT: MIT Press.

Gerring, J. (2006): "Single-Outcome Studies: A Methodological Primer", International Sociology, 21, no. 5, 707-734, DOI: http://journals.sagepub.com/doi/abs/10.1177/0268580906067837 (accessed 8 August 2017) 
Global Policy Forum. (n.d.): “Global Policy Forum”. Failed States. Available at: https://www.globalpolicy.org/nations-a-states/failed-states.html_(accessed 24 Juni 17).

Gerring, J. (2004): 'What is a Case Study and What Is It Good for?', American Political Science Review, 98, 2, 341-354.

Gustafsson, Johanna (2017): "Single case studies vs. multiple case studies: A comparative study". Halmstad University Halmstad, Sweden. Available [online] at: http://www.divaportal.org/smash/get/diva2:1064378/FULLTEXT01.pdf (accessed 17 April 2017).

Hazen, Jennifer (2013): What Rebels Want: Resources and Supply Networks in Wartime, Cambridge: Cornell University Press.

Henderson, E \& J. Singer (2002): “"New Wars and Rumors of "New Wars"” in International Ineractions: Empirical and Theoretical Research in International Relations 28 no. 2: 165190. DOI: http://dx.doi.org/10.1080/03050620212098 (accessed 19 May 2017).

Hennink M., Inge Hutter, Ajay Bailey et al. (2011): Qualitative Research Methods London: SAGE publications.

Hey, Jeanne A. K. (2003): "Refining our understanding of small state foreign policy" in Small States in World Politics: Explaining Foreign Policy Behavior edited by Jeanne A. K. Hey, pp. 185-195, Colorado: Lynne Rienner Publisher Inc.

Human Security Centre, (2005): Human Security Report 2005: War and Peace in the 21st Century. New York: Oxford University Press.

Huntington, Samuel P. (1993): "Why International Primacy Matters." International Security, 17, no. 4: 68-83. DOI:10.2307/2539022 (accessed 10 May 2017).

International Committee of the Red Cross (2015): International Humanitarian Law: Answers to your questions. Geneva. ICRC 1-96

https://shop.icrc.org/droit-international-humanitaire-reponses-a-vos-questions-2568.html 
International Rescue Committee, (2001): Mortality in the Democratic Republic of Congo An Ongoing Crisis, 1-21. Available [online] at:

https://www.rescue.org/sites/default/files/document/661/2006-7congomortalitysurvey.pdf (accessed 26 August 2017).

Kaldor, M. (2005): "Elaborating the 'New War' Thesis" in Rethinking the Nature of War, edited by Duyvesteyn, I. And Angstrom, J. New York: Frank Cass.

Kaldor, M. (2013): “In Defence of New Wars". Stability: International Journal of Security and Development. 2 no. 1: 1-16, DOI: http://doi.org/10.5334/sta.at (accessed 10 April 2017).

Kaldor, M. (2012): New and Old Wars: Organized violence in a Global Era, $3^{\text {rd }}$ edition, Cambridge: Polity Press.

Kaldor, M., (2009): "New Wars: Counter-Insurgency or Human Security" The Broker. Available [online] at: http://www.thebrokeronline.eu/Special-Reports/Special-reportWho-is-the-enemy/New-wars (accessed 15 May 2017).

Kaldor, M. (2006): "The "New War" in Iraq." Theoria: A Journal of Social and Political Theory, no. 109: 1-27. URL: http://www.jstor.org/stable/41802310 (accessed 5 May 2017).

Kalyvas, Stathis N. (2001): "'New" and "Old" Civil Wars: A Valid Distinction?" World Politics 54, no. 1: 99-118.URL: http://www.jstor.org/stable/25054175 (accessed 12 May 17 2017).

Macpherson, William (2012): "Rwanda in Congo: Sixteen years of Intervention. African Arguments, Available [online] at: http://africanarguments.org/2012/07/09/rwanda-incongo-sixteen-years-of-intervention-by-william-macpherson/ (accessed 26 July 2017).

Melander, Erik, Thérese Petterson, Lotta Themnér (2016): “Oganized Violence, 1989-2015”. Journal of Peace Research. 53, no. 5: 727-742. DOI:

http://journals.sagepub.com/doi/10.1177/0022343316663032 (accessed 17 April 2017). 
Mueller, John (2004): The Remnants of War. London: Cornell University Press.

Münkler, Herfried (2004): The New Wars. Oxford: Polity Press.

Murison, Jude (2002): "The Politics of Refugees and Internally Displaced Persons in the Congo War", in The African Stakes of the Congo War edited by John F: Clark, New York: Palgrave Macmillan, 225-239.

N.a., (2002): “A report from Congo: Africa's Great War" The Economist, Available [online] at: http://www.economist.com/node/1213296 (accessed 15 June 2017).

Newman, E. (2004): The „New Wars ${ }^{\text {ee }}$ Debate: A Historical Perspective is Needed. Security Dialogue. 35 no. 2: 173-189. DOI: 10.1177/0967010604044975 (accessed 10 May 2017).

N.a. (2004): "From president to prison", $B B C$ News, Available [online] at: http://news.bbc.co.uk/1/hi/world/africa/3728807.stm (accessed 26 August 2017).

New York Times (1996-2003): "Congo" Available [online] at:

https://www.nytimes.com/topic/destination/congo_(accessed 24 May 2017).

French, Howard W. (1997): "Mobutu Sese Seko" New York Times, Available [online] at: https://partners.nytimes.com/library/world/090897obit-mobutu.html (accessed 27 August 2017)

Nienaber, Georgianne, Obadias Ndaba (n.d.): "Why the Democratic Republic of Congo Is a Failed State" Huffington Post, Available [online] at: http://www.huffingtonpost.com/georgianne-nienaber/why-the-democraticrepubl_b_1676305.html (accessed 8 July 2017)

Nzongola-Ntalaja, Georges (2011): "Patrice Lumumba: the most important assassination of the $20^{\text {th }}$ century" The Guardian, Available [online] at:

https://www.theguardian.com/global-development/poverty-matters/2011/jan/17/patricelumumba-50th-anniversary-assassination (accessed 27 August 2017). 
Paterson, Barbara L. (2010): "Within-Case Analysis" in Encyclopedia of Case Study Research. Edited by. Mills, Albert J., Gabrielle Durepos and Elden Wiebe, California: SAGE Publications: 970-972.

Reno, William (2011): Warfare in Independent Africa, Cambridge: Cambridge University Press.

Reyntjens, Filip (1999): "Briefing: The Second Congo War: More than a Remake", African Affairs, 98, no. 391, 241-250. DOI: https://doi.org/10.1093/oxfordjournals.afraf.a008010 (accessed 1 April 2017).

Reyntjens, Filip (2001): "The Democratic Republic of Congo: from Kabila to Kabila", African Affairs, 100, no. 399, 311-317, URL: http://www.jstor.org/stable/3518770 (accessed 29 March 2017).

Reyntjens, Filip (2009): The Great African War: Congo and Regional Politics 1996-2006, Cambridge: Cambridge University Press.

Roberts, Les (2000): Mortality in Eastern DRC: Results from Five Mortality Surveys, New York: International Rescue Committee.

Rose, Gideon (1998): "Neoclassical Realism and theories of Foreign Policy". World Politics, 51 no.1: 144-172 URL: http://www.jstor.org/stable/25054068 (accessed 3 August 2017)

Schouten, P. (2009): “Theory Talk \#30: Mary Kaldor on Framing War, the Military-

Industrial Complex, and Human Security", Theory Talks. Available [online] at: http://www.theory-talks.org/2009/05/theory-talk-30.html (accessed 24 August 2017).

Shaw, Martin (2009): "Genocide in the Global Age", in The Routledge Handbook of Globalisation Studies, edited by Bryan S. Wilson London: Routledge: 312-27. 
Shaw, Martin (2000): "The Contemporary Mode of Warfare? Mary Kaldor's Theory of New Wars." Review of International Political Economy 7, no. 1, 171-80. URL:

http://www.jstor.org/stable/4177336 (accessed 12 May 2017)

Shaw, Martin (2003): War \& Genocide: Organized Killing in Modern Society. Cambridge: Polity Press.

Small, Melvin and J. David Singer (1972): The Wages of War 1816-1965: A Statistical Handbook, New York: Wiley \& Sons.

Smith, M. (2003): "Guerrillas in the Mist: Reassessing Strategy and Low Intensity Warfare", Review of International Studies. DOI: 10.1017/S0260210503000020 (accessed 20 May 2017)

Taylor, Adam, Laris Karklis (2016): "This remarkable chart shows how U.S. defence spending dwarfs the rest of the world. Washington Post, Available [online] at: https://www.washingtonpost.com/news/worldviews/wp/2016/02/09/this-remarkablechart-shows-how-u-s-defense-spending-dwarfs-the-rest-of-theworld/?utm_term=.575a6c22e376_(accessed 24 July 2017).

Taylor, Steven J., Robert Bogdan, Marjorie Devault (2016): Introduction to Qualitative Research Methods: A Guidebook and Resource $4^{\text {th }}$ edition, New Jersey: Wiley \& Sons.

Thom, William G. (1999): “Congo-Zaire's 1996-97 Civil War in the Context of Evolving Patterns of Military Conflict in Africa in the Era of Independence" Journal of Conflict Studies 19, no. 2: 1-16. Available [online] at: https://journals.lib.unb.ca/index.php/jcs/article/view/4358/5015 (accessed 10 August 2017).

Toshkov, Dimiter (2016): Research Design in Political Science, London: Palgrave Macmillan.

Turner, Thomas. (2007): The Congo Wars: Conflict Myth and Realty. London: Zed Books 
The International Institute for Strategic Studies (2006): Africa Vol. II., London: Routledge.

Thürer, Daniel (1999): "The 'Failed State' and International Law", International Review of the Red Cross 836: 731-761.

Union of International Associations, (n.d.): Yearbook, Available [online] at: https://www.uia.org/yearbook (accessed 25 July 2017).

United Nations Commission on Human Rights (1996): "Report on the Situation of Human Rights in Zaire, in accordance with Commission resolution 1996/77, E/CN.4/1997/6/Add. Available [online] at: http://www.refworld.org/docid/3ae6b0d18.html (accessed 20 July 2017

United Nations, General Assembly (2001): "Report of the Panel of Experts on the Illegal Exploitation of Natural Resources and Other Forms of Wealth of the Democratic Republic of the Congo: report of the Secretary-General S/2001/357'. Available [online] at:

http://www.securitycouncilreport.org/atf/cf/\%7B65BFCF9B-6D27-4E9C-8CD3-

CF6E4FF96FF9\%7D/DRC\%20S\%202001\%20357.pdf_(accessed 5 August 2017).

United Nations (1945) : “Charter of the United Nations”, I UNTS XVI, Available [online] at: https://treaties.un.org/doc/publication/cc/uncharter.pdf (accessed 25 August 2017).

United Nations (2010): Office of the High Commissioner for Human Rights "Report of the Mapping Exercise documenting the most serious violations of human rights and international law committed within the territory of the Democratic Republic of the Congo between March 1993 and June 2003" August 2010 Available [online] at http://www.ohchr.org/Documents/Countries/CD/DRC_MAPPING_REPORT_FINAL_E N.pdf (accessed 5 August 2017).

United Nations (n.d.): United Nations Organization Mission in the Democratic Republic of the Congo. "MONUC Background". Available [online] at:

http://www.un.org/en/peacekeeping/missions/past/monuc/background.shtml_accessed 29 July 2017), 
Uppsala Conflict Data Program (2017): UCDP Conflict Encyclopaedia, Available [online] at: www.ucdp.uu.se (accessed 15 August 2017) Uppsala University.

Van Creveld, Martin (1991): The Transformation of War. New York: The Free Press.

Van Evera, Stephen (1997): Guide to Methods for Students of Political Science. London: Cornell University Press.

Vlassenroot, Koen \& Timothy Raeymaekers (2004): Conflict and Social Transformation in Eastern DR Congo, Gent: Academia Press.

Wallerstein, Immanuel (1974): The Modern World System: Capitalist Agriculture and the Origins of the European World Economy in the Sixteenth Century. New York: Academic Press.

Waltz, Kenneth N, (1979): Theory of International Politics, Massachusetts: Addison-Wesley Publishing Company.

Williams, Christopher (2013): "Explaining the Great War in Africa: How Conflict in the Congo Became a Continental Crisis", The Fletcher Forum of World Affairs, 37 no. 2: pp: 81-100.

Yin, Robert K. (2009): Case Study Research: Design and Methods. London: SAGE Publications.

Yoo, Jiwon Amy (n.d.): “Kasavubu, Joseph (ca. 1910-1969)”, Blackpast.org, Available [online] at: http://www.blackpast.org/gah/kasavubu-joseph-ca-1910-1969 (accessed 27 August 2017),

Young, Crawford (2002): "Contextualizing Congo Conflicts: Order and Disorder in Postcolonial Africa”, in The African Stakes of the Congo War edited by John F: Clark, New York: Palgrave Macmillan, 13-33. 


\section{Appendix A - Timeline ${ }^{15}$}

\section{6}

February: Government in Zaire/DRC seals off refugee camps to force Rwandan refugees to return home.

June/July: Banyamulenge in South Kivu increasingly victimised and their organisation, Milima, banned.

September: Start of the "Banyamulenge rebellion" supported by Rwanda.

October:

- Hutu and Tutsi refugees flee refugee camps in order to escape increasing violence between Zairian/Congolese soldiers and local guerrilla groups. Rwandan government denies any part in the conflict. The "Banyamulenge", a group of Tutsi pastoralists who speak Kinyarwanda, attack the town of Uvira. Subsequently, all "Banyamulenge" are expelled from the DRC and are given two weeks to vacate. AFDL is founded in Rwanda with Laurent Kabila and Paul Kagame at the head of the organisation.

- 18 October: Fall of Uvira.

- 28 October: Fall of Bukavu.

- 31 October: Fall of Goma.

November:

- Rebel leader announces a unilateral three-week cease fire between Zairian/Congolese army and Tutsi guerrilla rebels in order to supply food and water to the endangered refugees caught in the cross-fire. UN troops invited back to aid said refugees. Buffer zone established along Rwandan and Burundian borders. Hundreds of thousands of Rwandan refugees "repatriated", while hundreds of thousands of others flee westwards.

- 4-5 November: Nairobi-I regional summit on the Zairean/Congolese crisis.

November-December:

\footnotetext{
${ }^{15}$ New York Times 1996-2003; Reyntjens, 2009: 291-295 \& Turner 2007: 199-204
} 
- Aborted attempts at launching an international "military-humanitarian" intervention to protect the Rwandan refugees.

\section{December:}

- UN presses for truce in order to help the trapped refugees in eastern Zaire/DRC

- $\quad$ 16-17 December: Nairobi-II regional summit.

- 17 December: Mobutu returns to Kinshasa from France.

- 18 December: General Mahele appointed chief of staff of the FAZ.

- 25 December: Fall of Bunia.

\section{7}

January:

- 8 January: Mobutu returns to France.

- 22 January: Sahnoun appointed Special Representative of Kofi Annan.

\section{February:}

- Angola joins the anti-Mobutu coalition.

- 18 February: UNSC adopts Resolution 1079, outlining a five-point peace plan

- 28 February: Fall of Kindu.

March:

- 15 March: Fall of Kisangani.

- 19 March: Nairobi-III regional summit.

- 21 March: Mobutu returns to Kinshasa.

April:

- Kabila and allies control Kasai and Katanga; Angolan troops pour across border. Massive slaughter by the RPA/RPF of Rwandan refugees in Zaire/Congo. Later stated by a UN inquiry to have involved war crimes and crimes against humanity, possibly genocide.

- 2 April: Tshisekedi appointed prime minister.

- 4 April: Fall of Mbuji-Mayi.

- 9 April: Fall of Lubumbashi. Tshisekedi fired as prime minister and replaced by General Likulia. 
- 29 April: Fall of Kikwit.

May:

- Kinshasa falls to Kabila and his allies. Kabila declares himself President of the now Democratic Republic of Congo. Clinton administration accepts Kabila as President of Zaire/DRC. New constitution comes into place.

- 4 May: Meeting Mobutu-Kabila on board SAS Outeniqua in the port of Pointe-Noire.

- 17 May: Fall of Kinshasa.

- 29 May: Kabila sworn in as president.

July:

- Paul Kagame says Rwanda planned and directed the "rebellion".

\section{August:}

- UN team begins to investigate fate of Hutu refugees. Investigators leave in March 1998, their work unfinished. Increased fighting in northwestern Rwanda, thousands of civilians killed by the RPA/RPF.

December:

- 1 December: Rwanda Lt. James Kabarebe appointed interim chief of staff of the FAC.

- 31 December: Hundreds of civilians killed during fighting near Bujumbura airport.

1998

February:

- Mutiny of Banyamulenge soldiers of Bukavu.

- 15 February: Kagame replaces Kanyarengwe as chairman of the political wing of the RPF.

May:

- 17 May: Rwanda and Uganda refuse to attend a conference on regional security, organised in Kinshasa to mark the first anniversary of the AFDL's victory.

July:

- 26 July: "Rwandan and other foreign military" ordered to leave the DRC. 


\section{August:}

- Anti-Kabila rebels, backed by Rwanda and Uganda, advance to gates of Kinshasa. Intervention of Zimbabwe, Namibia, and Angola turns the tides. Ceasefire talks in Zimbabwe fail.

- 2 August: Beginning of a new Congolese "rebellion" masterminded by Rwanda. Goma, Bukavu, and Uvira seized.

- 5 August: RPA raid on Kitona, defeated by Angolan intervention.

- 12 August: Creation of the RCD, with Ernest Wamba dia Wamba as chairman.

- 19 August: Deployment of Angolan, Zimbabwean, and Namibian troops in support of Kinshasa regime authorised at SADC (Southern African Development Community) meeting in Harare.

- 23 August: Fall of Kisangani. SADC summit in Pretoria.

September:

- Rebels face defeat in the west. Addis peace talks fail.

- 8 September: SADC summit in Victoria Falls.

- 13-14 September: First Syrte summit under Libyan auspices.

October:

- Rebels capture government stronghold of Kindu as peace talks collapse in Lusaka.

- 12 October: Fall of Kindu.

- 26 October: Uganda admits to having troops in the DRC.

November:

- Rwanda acknowledges its forces are fighting alongside RCD rebels. Newly created Uganda-backed MLC advances in the north.

- 6 November: Rwanda admits to having troops in the DRC.

December:

- Efforts to halt war make little progress at the OAU (Organisation of African Unity). Rebels accuse Angola and Zimbabwe of launching counter-offensive. 
$\underline{\text { March: }}$

- Government forces and allies seek to halt rebel advance towards diamond-rich city of Mbuji-Mayi.

April:

- 18 April: Second Syrte summit.

- 20 April: Launch of the CPP.

May:

- 16 May: The RCD splits, as Wamba dia Wamba retreats to Kisangani and sets up the RCD-ML. Émile Ilunga becomes chairman of the RCD-Goma.

May-June:

- Fighting between RPA and UPDF in Kisangani.

June:

- 11 June: Ugandan General James Kaxini creates the "province" of Kibali-Ituri and appoints Adéle Lotsove as governor.

July:

- A ceasefire is agreed upon and signed in Lusaka by all sides in the conflict except RCD, still locked in a factional dispute. RCD signs in August. Troops from Uganda and Rwanda, backing rival rebel factions, clash at Kisangani. Beginning of mass violence in Ituri.

- 3 July: MLC headquarters installed in Gbadolite.

August: 
- Continuing resentment towards Rwanda and Rwandan armies in Kinshasa. Ten days of heavy fighting between Rwandan and Ugandan armies in Kisangani. Wamba, forced to flee the city, settles in Bunia.

October:

- Start of deployment of MONUC.

\section{0}

February:

- UN Security Council authorizes 5,500-man force to monitor the ceasefire.

June:

- Tensions between Rwanda and Uganda erupt into the worst fighting yet in Kisangani. The adversaries later agree to leave the city in UN-brokered deal. Security Council authorizes Panel of Experts on the illegal Exploitations of Natural Resources in DRC. In Rwanda, the Speaker of Parliament, the Prime Minister and the President resign. Vice-President Kagame becomes President.

28 August:

- Arusha Accord on Burundi signed.

2001

January:

- A bodyguard kills President Laurent Kabila. Joseph Kabila replaces him. Ugandan forces the merger of the MLC and RCD-ML to form the FLC.

February:

- Joseph Kabila meets Rwandan President Kagame in Washington. Rwanda, Uganda, and rebels agree to UN-backed pull-out plan.

\section{March:}

- Rwanda declared a "hostile nation" by the Ugandan government.

April: 
- Experts panel says the warring parties are deliberately prolonging the war to plunder gold, diamonds, timber, and coltan.

May:

- International Rescue Committee says the war has killed 2.5 million people since 1998.

June-August:

- End of the Ugandan arranged liberation movement called the Front de Libération du Congo (FLC).

November:

- Wamba dia Wamba removed and replaced as chairman of RCD-ML.

2002

January:

- New UN Expert Panel to continue inquiry into pillage. Amnesty International accuses DRC security forces of an alarming increase in arbitrary arrests and detentions. Rwanda-backed RCD-Goma forms alliance with UPC of Thomas Lubanga in Ituri. Catholic bishop of Beni-Butembo accuses Bemba's MLC and Lumbala's RCD-N of cannibalism. Government asks UN Security Council to establish a UN criminal court to try rebels accused of atrocities.

- EU parliament calls for measures to punish persons found guilty of pillaging the resources of the DRC, including an investigation by the International Criminal Court into "acts of genocide and crimes against humanity committed in Africa and elsewhere, where such acts were perpetrated to illegally secure natural resources, such as iamonds, and timer".

- Ugandan Defence Minister says situation in Bunia is explosive and asks UN to send troops to take control of the area. Human Rights Watch says Uganda should be held responsible for human rights violations taking place in territories it occupies in the DRC.

February:

- Some 8,000 Maï-Maï militiamen, accused of cannibalism, are disarmed in Haut Lomani (Katanga). 
- Kampala and Kinshasa agree on modalities for the implementation of the Ituri Pacification Commission and for the withdrawal of Ugandan troops from the DRC.

- Belgian Senate commission on exploitation of natural resources in the DRC concludes that no illegal acts were committed by the people and companies investigated.

March:

- The UPC signs an accord with the Uganda People's Defence Force (UPDF). The UPDF and allied Lendu and Ngiti militias oust the UPC from Bunia. Parties to the interCongolese dialogue in Pretoria agree to a programme for the drafting of a constitution for a period of national transitional government eventually leading to democratic elections.

- Delegates of the Ugandan and DRC governments, different rebel groups, and ethnic militias operating in Ituri sign the Ituri Cessation of Hostilities Agreement in Bunia, under which the UPDF is to withdraw from the DRC on 24 April. The UPC does not sign.

- Security Council asks Secretary General Annan to increase the presence of MONUC, especially in Ituri, where violence has escalated in the recent past. It also asks Annan to increase the number of personnel in MONUC's human rights component to enhance the capacity of the Congolese parties to investigate all serious violations of international humanitarian law and human rights perpetrated in DRC since 1998.

- RCD-Goma appoints to its ranks four former army officers who have been condemned to death for the assassination of President Laurent Kabila.

April:

- In Sun City, South Africa, DRC government and rebel groups unanimously endorse a transitional constitution to govern DRC for two years. President Joseph Kabila to retain his post, supported by four vice presidents from rebel groups and the civilian opposition.

- Ituri Pacification Commission in inaugurated in Bunia. The commission includes representatives of the DRC, Ugandan and Angolan governments, MONUC, civil society bodies, a business people's association, political and military parties to the conflict in Ituri, and ninety grassroots communities.

- Kabila sworn in as interim head of state. 
- International Rescue Committee (IRC) reports that conflict in the DRC has cost more lives than any other since the Second World War.

- Government announces abolition of the Military Order Court, which has been criticized by national and international human rights organizations as failing to meet international fair trial standards.

May:

- Azaria Ruberwa, RCD-Goma secretary general, is named as his movement's candidate for the fourth and final vice presidential post for a two-year national transition government, joining the three vice presidential candidates already named: MLC leader Bemba; Kabila ally Yerodia; and Z'ahidi Ngoma from the unarmed opposition.

- UPC takes control of Bunia after six days of fighting. Five armed groups that have been fighting around Bunia sign an agreement in Dar es Salaam to cease hostilities and relaunch the Ituri peace process.

- Ugandan government vows to take legal action against all individuals identified by the Ugandan Judicial Commission of Inquiry as having been involved in the plunder of DRC's natural resources. However, it will ignore all other allegations made by the UN Expert Panel.

- Human Rights Watch and Amnesty International ask the UN to authorize the development of a rapid reaction force to protect civilians in Ituri, saying that MONUC has been unable to protect civilians adequately.

- UN Secretary Council authorizes deployment of an interim emergency multinational force in Bunia, until 1 September. France offers to lead the force, and will contribute 750 troops, with the remainder to come from other EU states.

June:

- Secretary General Annan recommends a one-year extension of MONUC's mandate and calls for an increase in authorized military strength from 8.700 to 10.800. An advance unit of French soldiers arrives in Bunia to prepare for the arrival of an estimated 1.400 multinational peace enforcement troops. EU agrees to deploy troops as part of the multinational force in Bunia, codenamed "Artemis".

- RCD-Goma captures Lubero, North Kivu as a ceasefire deal for the region is signed in Bujumbura amon all parties to the conflict: Mouvement de libération (RCD-K/ML) to which Kinshasa is allied. 
- Kabila names is transitional government.

July:

- Amos Namanga Ngongi (Cameroon), Special Representative of Secretary Gernal Annan to the DRC, completes two-year mandate, to be replaced by US diplomat William Swing. MONUC announces that a 3,800-strong force will be deployed in Ituri and other locations, to ensure the 1 September handover from the French-led multinational peace enforcement mission.

- EU high representative for the common foreign and security policy, Javier Solana, calls on UN Security Council to authorize a stronger mandate for MONUC, similar to that of the EU-led multinational peace enforcement mission deployed in Bunia.

- The mutilated bodies of twenty-two civilians, primarily women and children, are discovered by a patrol of the EU-led multinational force, north of Bunia. Rival ethnic militias in Ituri agree to disarm and participate in joint verification exercises.

- Eleven Congolese civilians murdered near the town of Baraka in South Kivu, allegedly by fighters belonging to an alliance of the FDD rebel group from neighbouring Burundi; Rwandan former military; and Congolese Maï-Maï.

- During the first meeting, the new transitional government resolves to make resolving the conflict in Ituri a major priority, with a consultative committee to be sent to the area imminently.

- UN Security Council unanimously adopts resolution giving MONUC a stronger mandate and increasing its authorized strength from 8,700 to 10,800 troops. The Council also extends the mission's mandate for another year, until 30 July 2004 and institutes a twelve-month arms embargo against foreign and Congolese armed groups in the east.

\section{August:}

- Controversy over military leader nominees resolved as RCD-Goma submits a revised list of candidates for top military posts.

- Kabila names officers to lead the nation's unified national military, incorporating elements from all former armed rebel groups signatory to a national power-sharing accord, as well as Maï-Maï militias. Human rights activists criticize the appointment of military officials alleged to have been involved in massacres in Kisangani in 2002, including Amisi and Nkunda of the RCD-Goma. 
- Ituri militias agree to work with transitional government to restore state authority across the region.

- UN Security Council authorizes EU-led multinational peace enforcement mission in Bunia to provide assistance to MONUC, as the former withdraws and the latter is reinforced and deployed in and around Bunia.

- UN Special rapporteur on the human rights situation in the DRC, Iulia Motoc, says there are indications that genocide may have occurred in Ituri.

\section{September:}

- The French-led multinational force in Bunia hands over security duties to MONUC.

- The leadership of newly unified national military is inaugurated in Kinshasa. DRC military chief of staff Lieutenant General Liwanga Mata Nyamunyobo summons three officers of the RCD-Goma, including Brigadier General Laurent Nkunda, to appear before a military court for having refused to take part in the inauguration of the newly unified national army.

- MONUC arrests about 100 people, including two UPC leaders, after fighting erupts during a protest of MONUC's Bunia without Arms' campaign.

- Two rival militias in Bunia - the primarily Hema UPC and the primarily Lendu FNI agree to allow the free circulation of people and goods in the region.

- The Office of the Prosecutor of the ICC says it will investigate the role of the businesses operating in Europe, Asia, and North America in fuelling crimes against humanity in the DRC.

\section{3}

- Opposition politician Etienne Tshiekedi returns to Kinshasa after self-imposed twoyear exile, but says he will not take part in the transitional government.

June:

- Two UN peacekeepers are abducted and killed in the northeastern town of Mongwalu.

\section{August:}

- A new interim Parliament meets for the first time in Kinshasa. President Kabila inaugurated the Parliament and is accompanied by his four new vice presidents. 


\section{October:}

- An agreement to cease hostilities between forces of General David Padiri Bulenda's Maï-Maï militia and the RCD-Goma former rebel movement is signed in Shabunda, South Kivu.

- Sixteen civilians, primarily women, killed during an attack on the village of Ndunda, $30 \mathrm{~km}$ north of the town Uvira, South Kivu. Witnesses tell MONUC that the killings were carried out by a group of twenty who spoke Kirundi, national language of neighbouring Burundi.

- Government says it will no longer tolerate the presence on its national territory of Rwandan fighters linked to the genocide (FDLR).

- The International Committee to Accompany the Transition (CIAT) chides the national unity government for a wide range of delays that "risked jeopardizing the holdings of nationwide elections within the next twenty-four months".

- UN Panel of Experts on the Illegal Exploitation of Natural Resources and Other Forms of Wealth of the DRC releases its final report, listing names of individuals, companies, and governments involved in the plunder of gems and minerals, and recommending measures to be taken. Rwandan Foreign Minister Charles Murigande announces that his government will set up a commission to investigate two cases of alleged illegal exploitation of the DRC's resources by Rwandan companies and individuals.

\section{November:}

- MONUC accuses government of blocking an inquiry into the crash landing of a cargo plane believed to have been transporting illegal arms to groups in South Kivu province.

- Voluntary return to neighbouring Rwanda of 103 members of the FDLR, including its leader Paul Rwarakabije.

- Some 2,000 people associated with Maï-Maï militias are demobilized in Kindu to either return to civilian life or to be integrated into the national army.

- DRC and Rwanda recommit themselves to completing the repatriation of Rwandan fighters (Interhamwe ex-FAR in the Congo) within a year.

- Ugandan president Musebeni's younger brother - Lieutenant General Salim Saleh resigns amidst persistent allegations that he spearheaded his country's plunder of natural resources in the DRC during nearly five years of Ugandan occupation. 
- UN Security Council urges the transitional government to adopt a national disarmament, demobilization, reintegration (DDR) programme, and to accelerate reform of the army and police.

- UNICEF and the government launch a national campaign to promote education of all girls. 


\section{Appendix B - Key fighting units in the Congo Wars ${ }^{16}$}

\section{United Nations:}

MONUC/MONUSCO: United Nations Mission in the Democratic Republic of Congo.

\section{National Armies:}

RPF (Rwandese Patriotic Front): Rwandan political wing of Uganda-based Tutsi rebel group led by Paul Kagame that chased out the genocidaires in 1994. Now the ruling Rwandan political party.

FARDC or FAC (Forces Armées de la Républic Démocratique du Congo): Army of Democratic Republic of the Congo.

FAZ (Zairean Armed Forces): Army of Zaire(now Congo) under Mobuto Sese Seko

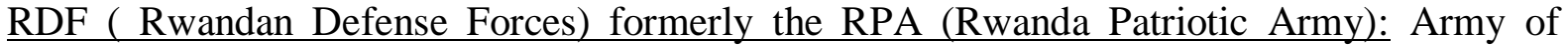
Rwanda (dominated by Tutsi).

UPDF (Ugandan People's Defense Force): Army of Uganda.

ZNA ( Zimbabwe National Army): Army of Zimbabwe, formed from the militias ZANLA and ZIPRA_Political Parties.

FAB (Forces Armées Burundaises): Army of Burundi (dominated by Tutsi, cooperates with the RCD and RDF).

\section{Militias:}

RCD-ML: Ugandan-backed group led by Mbusa Nyamwisi. Active in North Kivu and Ituri Province. See RCD-K/ML. Is reported to be accepting arms shipments from Kinshasa, in agreement with Uganda, that are shared with the FDLR against Tutsi forces.

\footnotetext{
${ }^{16}$ Uppsala Data Conflict Program, 2017
} 
APC (Armeé du Peuple Congolais) or (Armee Populaire Congolaise): The military wing of the RCD-ML.

RCD-N (RCD-National): Ugandan-backed rebel group led by Roger Lumbala that split from the RCD-K/ML and is now allied with the MLC.

RDR (Rassemblement Démocratique pour le Rwanda): Rwandan Hutu militia, successor organization to the Interahamwe in Congo that morphed into the ALIR.

SPLA (Sudanese People's Liberation Army): Sudanese militia.

UNITA (National Union for Total Independence of Angola): Angolan faction; officially demilitarised in 2002.

UPC (Union of Congolese Patriots): Political and militia group based in Ituri, north-eastern DRC.

FDLR (Democratic Forces for the Liberation of Rwanda): Congolese Hutu group created in 2000 after the Kinshasa-based Hutu command and Kivu-based ALIR agreed to merge and announced in March 2005 that they were abandoning armed resistance.

ADF/NALU (Allied Democratic Forces/National Army for the Liberation of Uganda): Ugandan rebel group active in western Uganda with rear bases in the DRC.

ADFL (Alliance of Democratic Forces for the Liberation of Congo): Rwanda-Uganda backed alliance.

ALIR (Army for the Liberation of Rwanda): Rwandan Hutu militia based in the Kivus since early 1997. A successor organization to the Interahamwe and RDR they merged with FDLR in September 2000.

Banyamulenge: Tutsis in South Kivu active in the ADFL and in the ANC. 
CNDD-FDD/FDD (National Council for the Defense of Democracy-Forces for the Defense of

Democracy): Burundian militia.

FLC (Front de Libération du Congo): Ugandan militia formed from the MLC, RCD-N and RCD-ML to centralize control of Equateur and Orientale provinces in 2000.

FLN or FROLINA (National Liberation Front): Burundian Hutu militia group.

FNI (Front for Nationalist Integration): Ugandan militia.

Interahamwe: Rwandan Hutu militia responsible for the genocide who were forced into eastern Congo, where they were known as the Rassemblement Démocratique pour le Rwanda.

LRA (Lord's Resistance Army): Christian cult from Uganda

Maï-Maï: An umbrella term for Congolese militia groups generally opposed to foreign occupation. Consists of several ethnic minority groups.

MLC (Movement for the Liberation of Congo): Ugandan-backed militia led by Jean-Pierre Bemba. Created 1998 and often used as erroneous shorthand to refer to all Ugandan-backed rebel forces in the DRC.

NALU (National Army for the Liberation of Uganda): Ugandan rebel group along the border with the DRC that merged into the ADF in 1996.

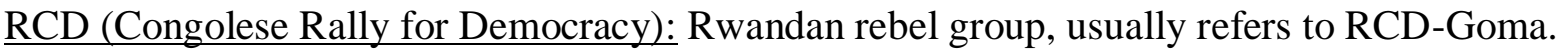

RCD-Congo: Faction of RCD-Goma led by Kin-Kiey Mulumba that broke off in June 2002.

RCD-Goma: A Rwandan-backed rebel group created in the town of Goma in August 1998 to fight Laurent Kabila.

ANC (Armée Nationale Congolaise): The military wing of RCD-Goma. 
RCD-K: Ugandan-backed rebel faction led by Wamba dia Wamba that broke from RCD-Goma in March 1999. Became the RCD-ML led by Nyamwisi in September 1999. Also known as RCD-Wamba. See RCD-K/ML.

RCD-K/ML (RCD-Kisangani/Mouvement de Libération): Refers to the RCD-K that became RCD-ML.

ALUR: Ethnic group residing in North-Eastern DRC. 


\section{Appendix C - Key individual actors in the Congo Wars}

Mobutu Sese Seko: Mobutu Sese Seko Kuku Ngbendu Wa Za Banga was born Joseph Désiré Mobutu in 1930. He was the president of the Democratic Republic of the Congo from 1965 to 1997. He remained the DRC Zaïre in 1971. Mobutu formed an authoritarian regime, amassed vast personal wealth, and attempted to remove all colonial cultural influence. He enjoyed considerable support from the United States and Great Britain due to his anti-communist stance. Belgian forces helped Mobutu in a coup d'état against the nationalist government in the DRC where Mobutu assumed the role of army chief of staff before taking all power and the presidency in 1965. Mobutu established a one-party state in which all power was in his hands. He built a centralised state and collected a large personal fortune through economic exploitation and corruption. Under his reign, the country suffered from inflation, a large debt, and a massive currency devaluations. He became notorious for corruption, nepotism, and embezzlement as well as extravagances. He was overthrown in the First Congo War by Laurent-Désiré Kabila who exiled Mobutu in 1997. He died of prostate cancer shortly after his exile from the DRC (French 1997).

Patrice Lumumba: A Congolese independence leader and the first democratically elected prime minister of the Congo. He played an important role in his country's independence from Belgium in 1960 as a founder and leader of the mainstream Mouvement National Congolais (MNC) party. Lumumba sought assistance from the wrong people at the wrong time (the Soviet Union) which lead to his imprisonment and execution in 1961. Lumumba does not play any role in the two Congo Wars, but he is notable for the fact that he serves as an inspiration for fair democracy still today in the Congo and for the wider Pan-African movement (NzongolaNtalaja 2011).

Jospeph Kasa-Vubu/Kasavubu: Was the first president of the newly democratised Congo. He remained in office from 1960-1965 when he was overthrown by Mobutu Sess Seko. Kasavubu preferred a more decentralised form of government that gave autonomous powers to provinces under a federal system. His role was far less influential than Lumumba's role as prime minister. In 1965, he was placed under house arrest and died in 1969 (Yoo n.d.)

Laurent-Désiré Kabila: Served as the third president of the Democratic Republic of the Congo from May 1997 until his assignation in January 2001. In 1962 he first appeared in the political 
sphere in Congo when he was appointed to the provincial assembly for North Katanga. He was a known as a revolutionist in his early career and was noted by Che Guevara as having "genuine qualities of a mass leader" but lacking in "revolutionary seriousness" (heimild). In 1967, Kabila formed the People's Revolutionary Party (PRP) and with the support of China, the PRP created a secessionist Marxist state in South Kivu province. Kabila's state came to an end in 1988, and Kabila left the Congo and stayed in Uganda where he met Yoweri Museveni and Paul Kagame. In 1996, Kabila returned to the Congo where he led a full-scale rebellion against Mobutu as the head of the AFDL. In 1997, Kabila sent Mobutu into exile and declared himself president, he was officially sworn into office in May 1997. He changed the then-name of the country from Zaïre to the Democratic Republic of the Congo and suspended the ruling constitution. His rule has been characterised as authoritarianism, corruption, and human rights abuses. During the Second Congo War, general satisfaction with Kabila was non-existent, and he was assassinated in January 2001 (Dunn 2002; C. Kabuya-Lumuna 2002).

Paul Kagame: Current President of Rwanda, inaugurated in 2000. Kagame commanded the rebel force RPF that ended the 1994 Rwandan genocide. He was then chosen as Vice President of Rwanda and known as the de facto leader of the country. He controlled the national army and maintained law and order. Kagame sponsored the two Congo Wars, in the first war backing Kabila's coup d'état, and in the second war backing the rebel forces against the new president, Laurent Kabila and his successor and son, Joseph Kabila. Kagame is known for his nationalism and dictatorship, and some say he holds Rwanda in a stronghold of fear, controlling all information flow and media coverage. He continues to refuse to cooperate with international organisation with regard to the two Congo wars. Rwanda is an authoritarian one-party state in praxis, even though Kagame denies it. A 99\% win in presidential elections is highly unusual, though not entirely unusual with the help of some corruption (Burke 2017).

Pasteur Bizimungu: President of Rwanda from 1994-2000, Kagame's predecessor (BBC 2004).

James Kabarebe: Rwandan military officer. Served as RPF commander and an AFDL strategist and commanding officer of the RDF in Congo. He was appointed head of the Congolese army FAC by Kabila after the First Congo War. He was asked to leave the Congo in 1997, and in the Second Congo War he was one of the commanders of the anti-Kabila rebellion. He was then appointed Chief of Defence Staff in the RDF (Reyntjens 2009). 
Ernest Wamba dia Wamba: A professor chosen as the head of the RCD in the Second Congo War. Later he seized control of the new RCD-ML/RCD-Kisangani backed by Uganda (Reyntjens 2009).

Émile Ilunga: Replaced Wamba dia Wamba as the leader of the RCD. Later he became the leader of the new RCD-Goma, the mainstream rebel movement backed by Rwanda when the split within the RCD occurred (Turner 2007).

Robert Mugabe: President of Zimbabwe since 1987.

Yowri Museveni: President of Uganda since 1986.

Joseph Kabila: President of the DRC since 2001. Laurent Kabila's successor and son. 


\section{Appendix D - Maps $^{17}$}

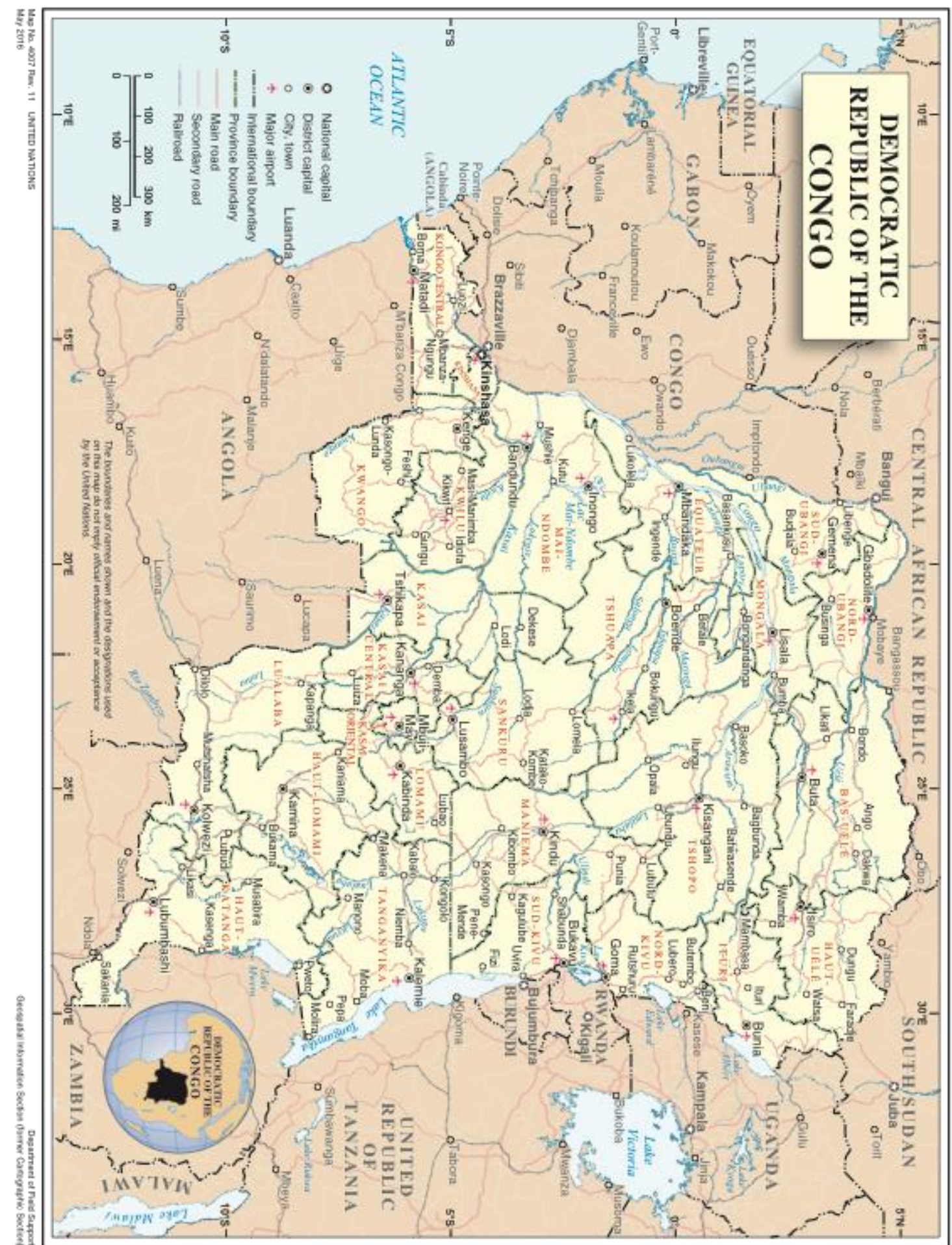

Map 1 The Democratic Republic of the Congo

${ }^{17}$ United Nations, 1999-2015. Available online at: http://www.un.org/Depts/Cartographic/english/htmain.htm 


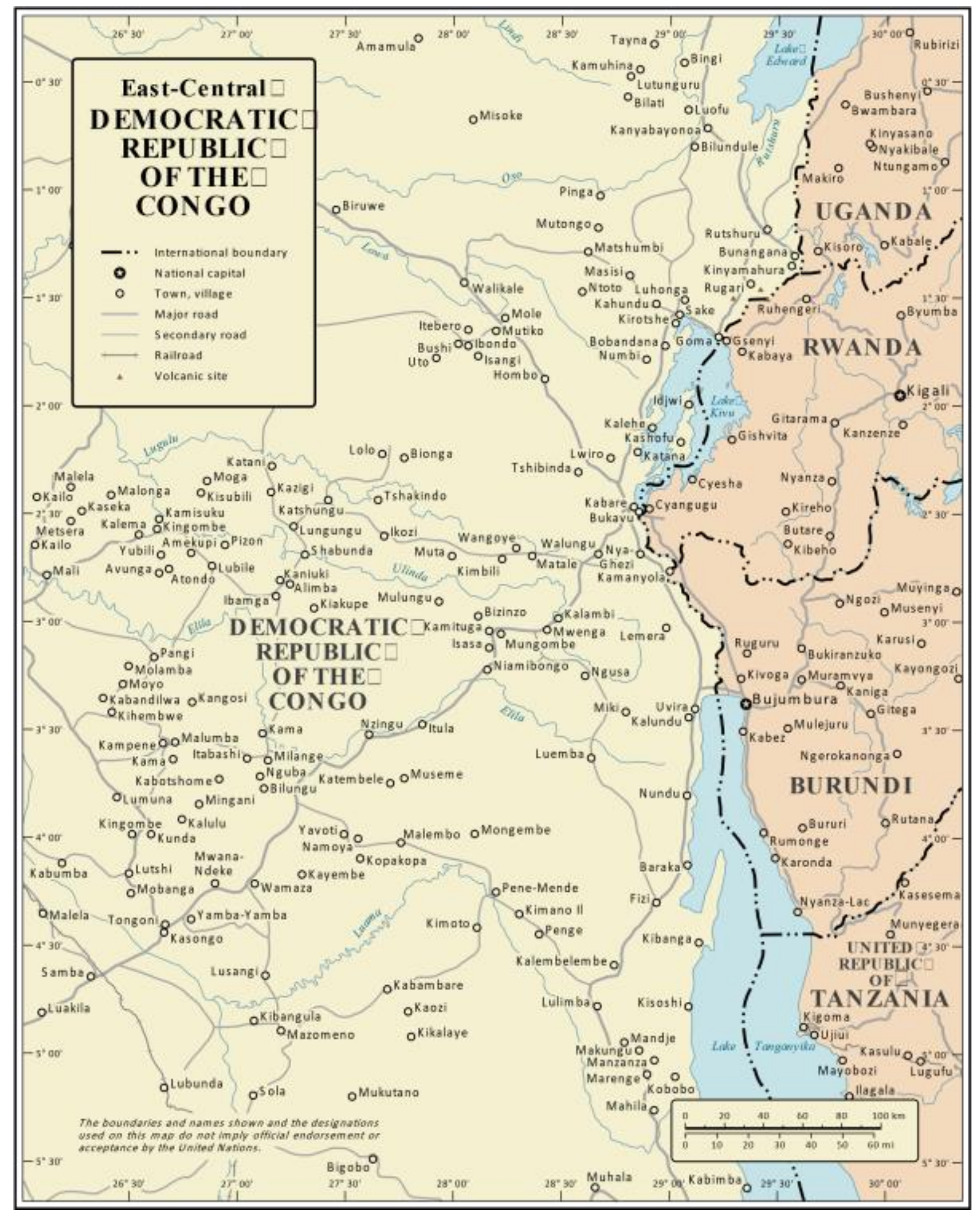

Map 2 East-Central of the Democratic Republic of the Congo 


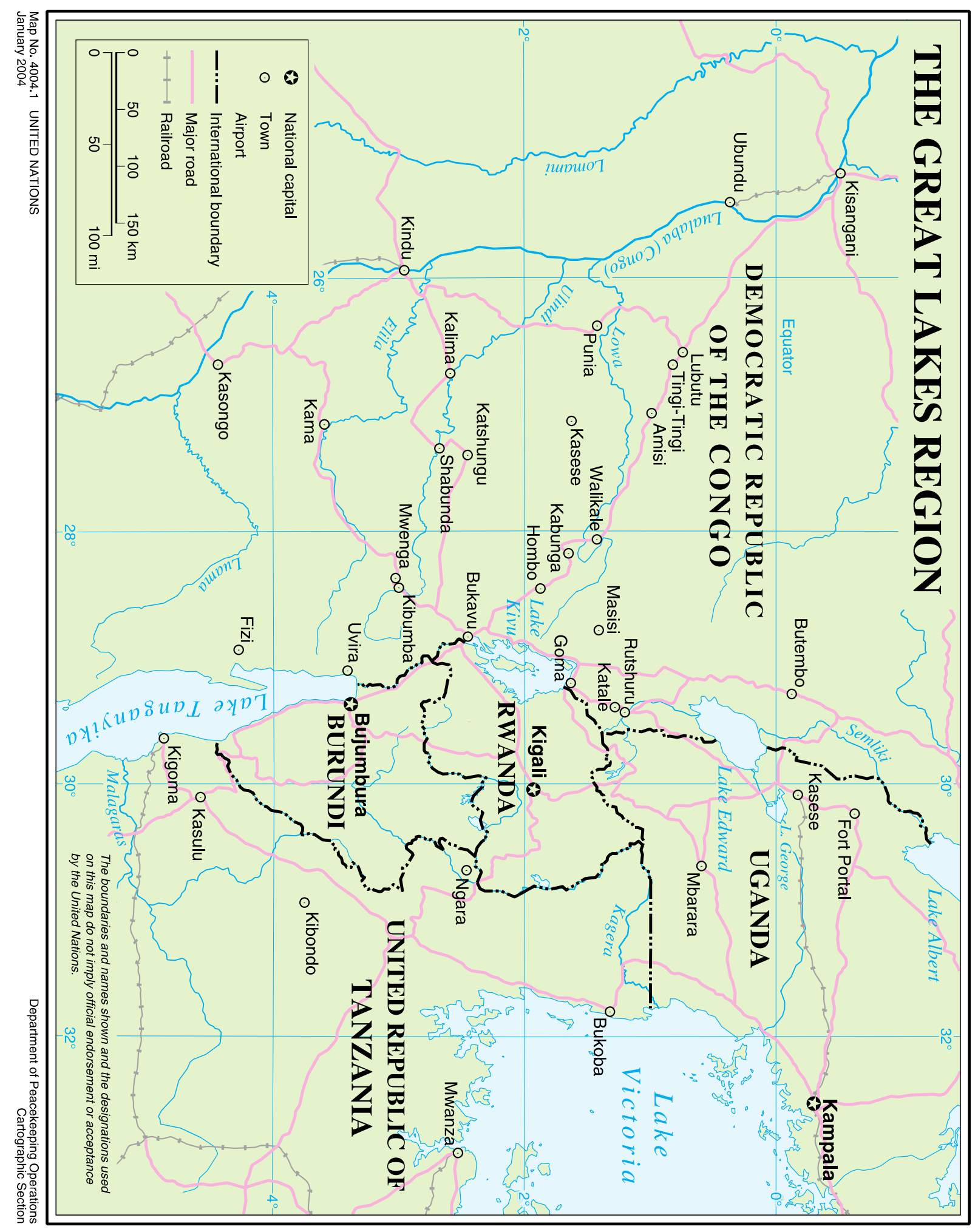

Map 3 The Great Lakes Region 